Portland State University

PDXScholar

1988

\title{
An experiment testing the Bolinger principle to teach gerunds and infinitives
}

Juliet Rosemarie Vawser

Portland State University

Follow this and additional works at: https://pdxscholar.library.pdx.edu/open_access_etds

Part of the Bilingual, Multilingual, and Multicultural Education Commons Let us know how access to this document benefits you.

\section{Recommended Citation}

Vawser, Juliet Rosemarie, "An experiment testing the Bolinger principle to teach gerunds and infinitives" (1988). Dissertations and Theses. Paper 3853.

https://doi.org/10.15760/etd.5737

This Thesis is brought to you for free and open access. It has been accepted for inclusion in Dissertations and Theses by an authorized administrator of PDXScholar. Please contact us if we can make this document more accessible: pdxscholar@pdx.edu. 
AN ABSTRACT OF THE THESIS OF Juliet Rosemarie Vawser for the Master of Arts in English: TESOL presented Feburary 22, 1988.

Title: An Experiment Testing the Bolinger Principle to Teach Gerunds and Infinitives.

APPROVED BY MEMBERS OF THE THESIS COMMITTEE:
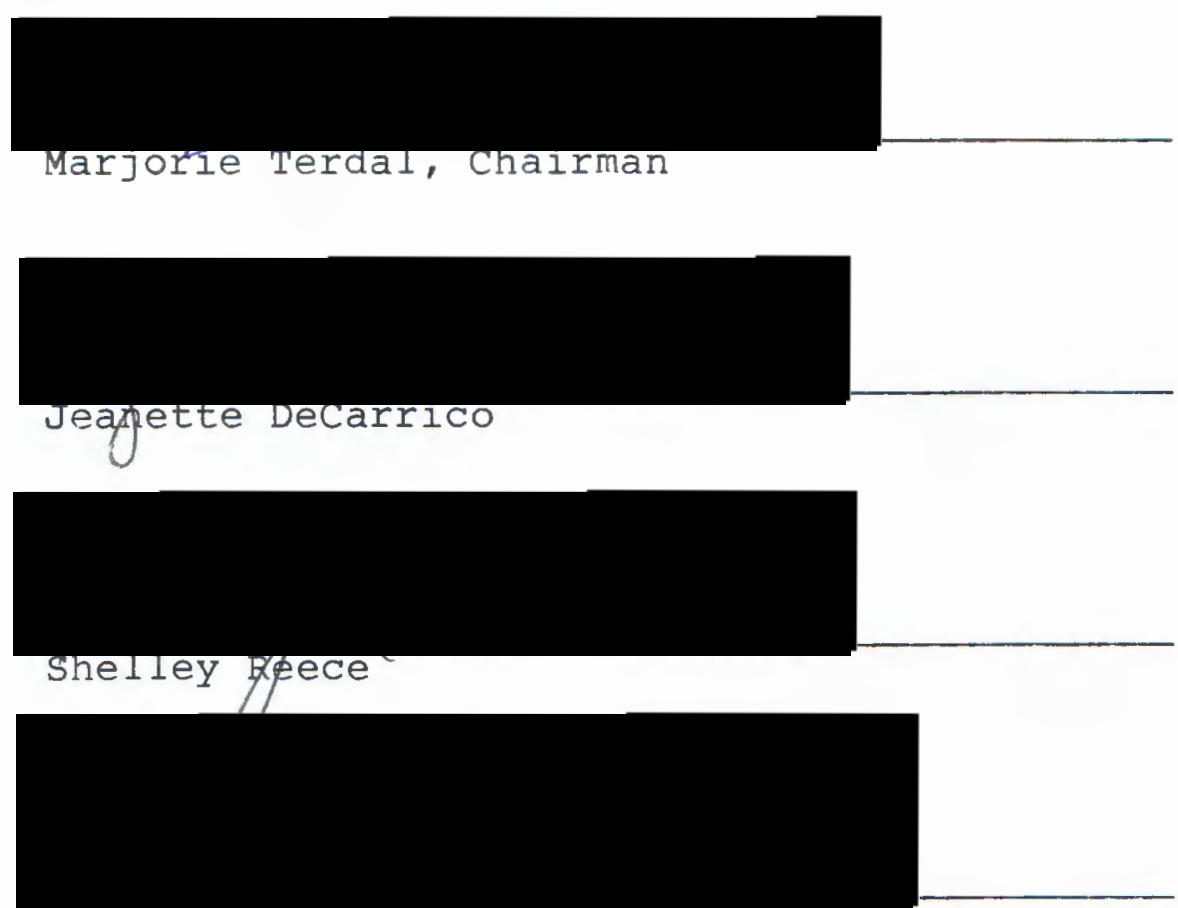

Francoise paheau

Gerunds and infinitives persist in being a major problem for students of English as a Second Language. Therefore, Bolinger's (1968) principle appeared to be an attractive alternative to teaching gerunds and infinitives 
as opposed to the usual way of list memorizing.

A group of 101 ESL learners ranging in the mid to upper intermediate level was randomly distributed among two groups--experimental and control. They were given three tests prior to the experiment and three tests after treatment. Both groups were given the same contextualized materials. However, the experimental group was taught gerunds and infinitives using the Bolinger principle whereas the control group was taught gerunds and infinitives by list memorization.

Two hypotheses were posed:

1. Teaching ESL learners gerunds and infinitives using the Bolinger principle will result in significant improvement in discrete point tests.

2. Teaching ESL learners gerunds and infinitives using the Bolinger principle will result in significant improvement in the use of gerunds and infinitives in writing.

In order to measure improvement for the first hypothesis, two discrete point tests were administered to the subjects. Two t-tests were run to see if there was any difference between the experimental and control groups. The t-tests showed that the experimental group had improved significantly over the control group. A writing sample was used to measure the second hypothesis. Although this test was not able to be statistically analyzed, results showed that the experimental group again did better than the control group. 
AN EXPERIMENT TESTING THE BOLINGER PRINCIPLE

TO TEACH GERUNDS AND INFINITIVES

by

JULIET ROSEMARIE VAWSER

A thesis submitted in partial fulfillment of the requirements for the degree of

\author{
MASTER OF ARTS \\ in \\ ENGLISH : TESOL
}

PORTLAND STATE UNIVERSITY

1988 


\section{TO THE OFFICE OF GRADUATE STUDIES:}

The members of the Committee approve the thesis of Juliet Rosemarie Vawser presented Feburary 22, 1988.
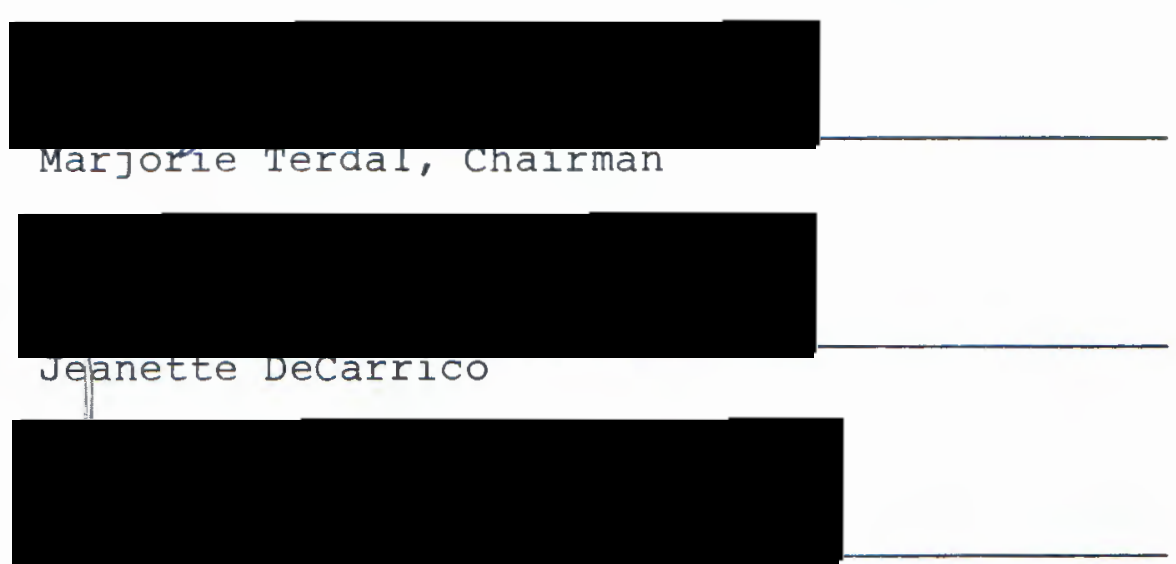

Shelley Regfce

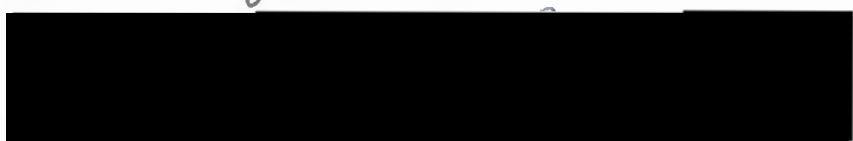

Francoise Paheau

APPROVED :

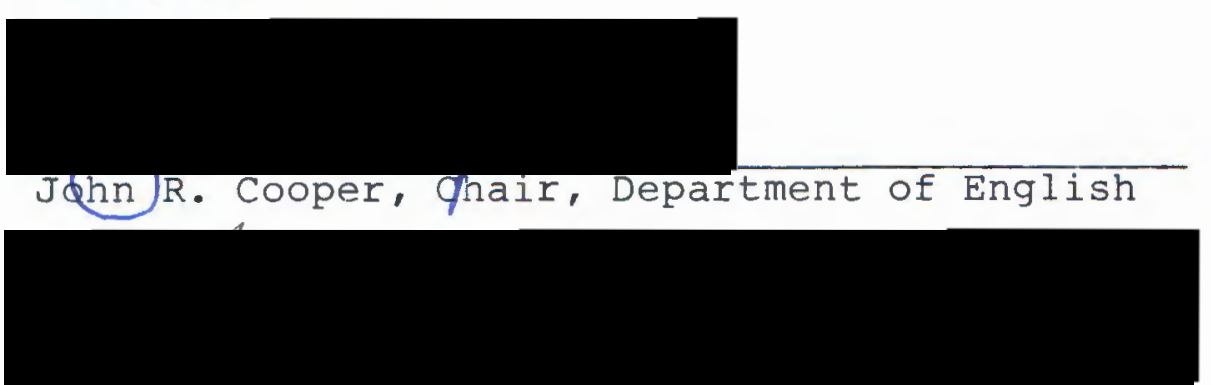

Bernard Ross, Vice Provost of Graduate studies 


\section{ACKNOWLEDGEMENTS}

Without the efforts of my advisor, Dr. Marjorie Terdal, this thesis would not have been achieved. Her expertise, critical thinking, and constructive criticism brought this experiment to fruition. Dr. Jeanette Decarrico was also instrumental in that she sparked my initial interest in the Bolinger principle. She was a source of encouragement throughout the process. Dr. Shelley Reece and Dr. Francoise Paheau provided helpful assistance through their invaluable insights. I would also like to thank Jane Dresser for allowing me to adapt her materials for my research.

Then I would like to express my thanks to all those who allowed me to use their classes for my research. Thank you Lorene Rollins, Diane Fox, Ruth Chapin, Colleen Carter, Cynthia Khawaja, Inger Van Waardenburg, Lynn Tullis, Liz Brunko, Todd Luedtke, Sally Hinrich, and Norm Yoshida.

Finally, I wish to express my deepest gratitude to my family who believed in me and encouraged me. Also, this research would never have been accomplished without my husband's constant help and support. It would not be fitting to end these acknowledgements without giving the 
honor to God who sustained me throughout this period of time.

"The Lord will accomplish what concerns me; Thy lovingkindness, o Lord is everlasting."

Psalm 138:8 
TABLE OF CONTENTS

PAGE

ACKNOWLEDGEMENTS • • • • • • • • • • • • . • • • • i ii

IIST OF TABLES . . . . . . . . . . . . . . . . vii vi

LIST OF FIGURES • • . • . • . . . . . . . . . • viii

\section{CHAPTER}

I INTRODUCTION • • • • • • • • • • • • • 1

Statement of Research Questions and

Hypotheses............ . 5

I I REVIEW OF THE LITERATURE . . . . . . . . 7

Other Researchers . . . . . . . 10

III METHOD . . . . . . . . . . . . . 19

Subjects . . . . . . . . . . . 19

Materials and Procedures . . . . . . 24

Description of the Experimental Group Lesson

Description of the Control Group

Lesson

Description of the Tests

Instruments . . . . . . . . . 33

summary . • . • . . . . . . . 35

IV RESULTS • • • • • • . • . • . • . 36

Results of Discrete Point Tests . . . . 36

Results of Sentence Combining Tests . . 39 


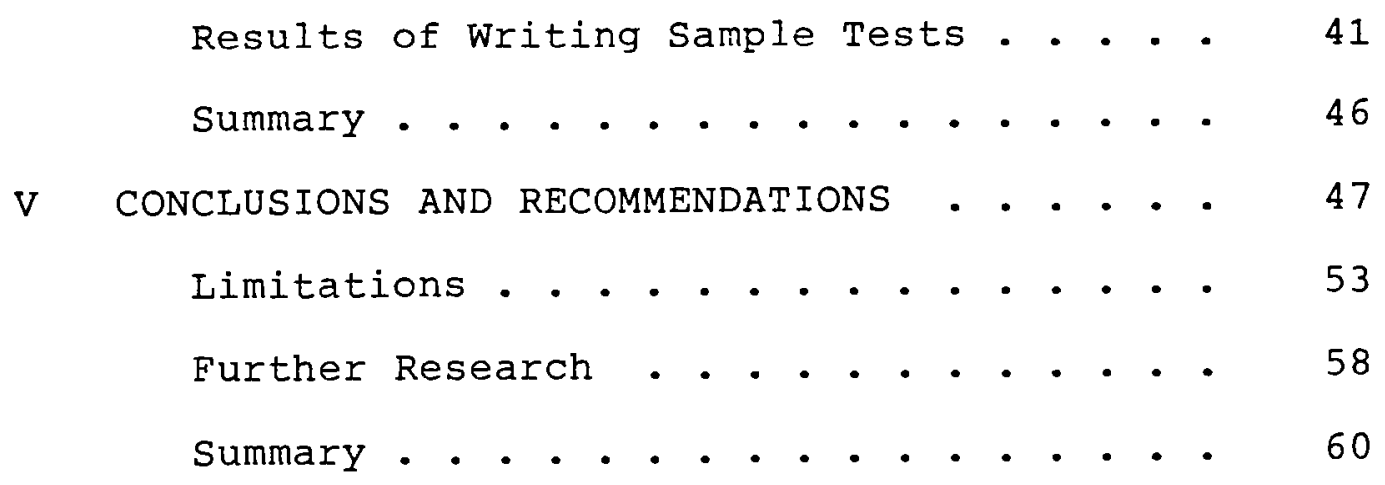

REFERENCES • • • • • • • • • • • • • • • • • . . 62

APPENDICES • • • • • • • • • • • • • • • • • • • • 65 


\section{LIST OF TABLES}

TABLE

PAGE

I Subjects Divided According to Texts Used . . • . 21

I Profile of Experimental and Control Groups . . 22

II Scores of the Discrete Point Tests . • . • • • 37

IV Scores of the Sentence Combining Tests . . . . . 40

V Results of the Writing Sample Tests . . . . . . 45

VI Frequency of Preceding Verbs used in the Writing

Sample Tests . . . . . . . . . . . 52 


\section{IIST OF FIGORES}

FIGURE

PAGE

1. Nationality Spread of Experimental and Control

Groups . . . . . . . . . . . . . 23

2. Age Spread of Experimental and Control Groups - 23

3. Length of Time in the U.S. . . . . . . . . . 24

4. Length of Time Studying English . . . . . . . . 24

5. Correct Usage of Gerunds and Infinitives . . . 42

6. Ratio of Total Usage of Gerunds and Infinitives 42

7. Ratio of Correct Usage of Gerunds and Infinitives . . . . . . . . . . . . 43

8. Ratio of Incorrect to correct Usage of Gerunds and Infinitives . . . . . . . . . . . . 44

9. Ratio of Incorrect Usage of Gerunds and Infinitives to Number of Words Written . .

10. Percentage of Mean Score for Discrete Point Tests . . . . . . . . . . . . 39

11. Percentage of Mean Score for Sentence Combining Tests . . . . . . . . . . . 40 


\section{CHAPTER I}

\section{INTRODUCTION}

Gerunds and infinitives persist in being a major problem for students of English as a Second Language (Celce-Murcia, Larsen-Freeman, 1983, p. 433). One explanation is that most languages have infinitives but not gerunds. Another possible explanation is that ESL learners pick up those complements that are most frequent in the English language and although infinitives are frequent, gerunds are not as frequent (Butoyi, 1977). Therefore, it appears that mother tongue interference and frequency of occurrence in English compound the problem for the ESL learner.

The usual way to teach gerunds and infinitives has been to have students memorize those verbs which take gerunds, those which take infinitives and those which take both. The educational trend today has moved away from rote memorization of language learning to a functional approach which is a more utilitarian one. Students as well as teachers are looking for ways to learn and teach language with a minimum of expenditure and a maximum of effectiveness. Therefore, it appears feasible that students 
would benefit from learning one rule as opposed to memorizing verb lists.

A more recent approach, advocated by Celce-Murcia and Larsen-Freeman has been the use of Bolinger's (1968) theory to present these grammatical concepts. An investigation was conducted to see if teaching gerunds and infinitives using the Bolinger principle would show any significant difference in discrete point tests and in writing as opposed to teaching these grammatical concepts using list memorization.

Bolinger (1968, pp. 119-127) claims that there seems to be an underlying semantic principle: The infinitive very often expresses something "hypothetical, future, unfulfilled," whereas the gerund typically expresses something "real, vivid, fulfilled." This principle explains why certain verbs take only the infinitive, e.g., want, hope, expect, agree, arrange, consent, decide, plan, ask, and warn. In looking at the meanings of these verbs, Bolinger points out that they all appear to express something in the future. On the other hand, verbs which only take the gerund, e.g., enjoy, detest, finish, admit, deny, discuss, complete, practice, resent, and mention express something that is going on or that has happened already, i.e., a person cannot enjoy something that he has not yet done or finish something that he has not yet 
started.

The questions raised by Bolinger are whether "two things different in form can ever be the same in meaning, and how the generative treatment of sameness is affected if the answer is no" (p. 121). What he asserts from his questions are that "the axiom of difference in form holds true, and that the complementizers are chosen for their own sake, not as a mechanical result of choosing something else. In short, for-to and ing contrast in meaning" ( $p$. 122)

Thus, Bolinger's theory stems from his observation that "a difference in syntactic form always spells a difference in meaning" (p. 127). The to and ing complementizers are used depending on the choice of the preceding main verb. The following are two examples:

$$
\begin{array}{ll}
\text { I enjoy singing. } & \text { I enjoy to sing. } \\
\text { I plan to sing. } & \text { I plan singing. }
\end{array}
$$

At first glance, the main verbs appear to take the gerund or infinitive forms arbitrarily. Bolinger proposes that these lists of verbs are not arbitrary and that a semantic feature is involved. Jespersen validates Bolinger's emphasis on meaning. According to Jespersen, (in Bolinger, 1968, p. 123) "the infinitive seems more appropriate than the gerund to denote the imaginative (unreal)." Joos (1963) also states 
that the ing complement has "validity of predication" ( $p$. 489); i.e., he asserts that the ing complement does indeed seem more appropriate to express something that is going on. Bolinger's conclusion is that a proper semantic contrast exists between the gerund and the infinitive--"Reification versus hypothesis or potentiality" (p. 124). Another aspect of difference shows up in "degrees of vividness." If something is real, then ing brings the action more sharply into focus" (p. 126). Verbs such as want, wish, hope, expect, command would therefore take the infinitive since they apply to unrealized possibilities. On the other hand, verbs such as enjoy, visualize, detest, understand, deny, approve take the gerund since they apply to reification of the action.

The rationale for doing this study is that if it made any appreciable difference, then ESL teachers could be made aware of this method and begin to incorporate it in their teaching of gerunds and infinitives. One reason for implementing this procedure would be improved scores on discrete point tests. If students began to use gerunds and infinitives in their writing and use them correctly, then this would be another reason for learning the Bolinger principle. 
Statement of Research Questions and Hypotheses

The research questions are as follows:

1. Will teaching gerunds and infinitives using the Bolinger principle result in any significant increase of students' ability to use these complements in discrete point tests as opposed to learning gerunds and infinitives through list memorization?

2. Will students' writing show any significant improvement in their use of gerunds and infinitives after having learned the Bolinger principle?

The hypotheses are as follows:

1. Teaching ESL learners gerunds and infinitives using the Bolinger principle will result in significant improvement in their ability to use gerunds and infinitives in discrete point tests.

2. Teaching ESL learners gerunds and infinitives using the Bolinger principle will result in significant improvement in their use of gerunds and infinitives in their writing.

In order to measure the first hypothesis, two discrete point pre and posttests were administered to the subjects. They will be explained in Chapter III.

To measure the second hypothesis, two writing samples were administered as part of the pre and posttests. The number of gerunds and infinitives in the object position was counted to see if students used them, and whether they used them correctly or incorrectly. At this point it should be noted that the Bolinger principle affects only the object position. Therefore, gerunds or infinitives elsewhere were not taken into consideration. 
The study was conducted as a quasi-experimental one. The independent variable was the teaching of gerunds and infinitives using the Bolinger principle in the experimental group and list memorization of verbs in the control group. The teaching procedure for both the experimental and control groups was inductive and the same contextualized exercises were used as well as the basic lesson plan. The dependent variables consisted of three pretests and three posttests.

The purpose of this study was to determine whether teaching gerunds and infinitives using the Bolinger principle made any difference in the results of discrete point testing as well as in students' writing; i.e., when these grammatical structures were called for, did students recognize that fact and use them correctly. 


\section{CHAPTER II}

\section{REVIEW OF THE LITERATURE}

A review of related literature will be discussed in this chapter. First, grammarians' definitions will be given. Then, ESL grammar texts copyrighted from 1972 to 1985 will be examined. The section on gerunds and infinitives will be surveyed to determine how these constructions are presented. Finally, other researchers who have contributed to this area will be reviewed in order to gain a more comprehensive understanding of these grammatical constructions.

Grammatical structures in any language are not always easily explainable by simple rules. In fact, most languages have many elaborate explanations of their grammars. Gerunds and infinitives are no exception. Traditional grammarians have attempted to define these grammatical structures and it would be well to review some of their definitions. Kruisinga (1929) defines the gerund as a verbal noun, "used to complete the meaning of a verb in the same way as a noun can be used" (p. 145). He says that in the object position, both gerunds and infinitives function as objects of the main verbs like noun objects. Poutsma basically agrees with 
Kruisinga in his analysis of the role of gerunds and infinitives in post-verbal positions (1929). He divides the verbs which take the infinitive into categories such as verbs of physical or mental perception, permission or command, affirmation, emotion, causation, will, etc. He does the same for gerundial verbs.

Jespersen (1966) defines a gerund as "the addition of ing from any verb (with the exception of may, shall, and a few other auxiliaries of the same type" (p. 320). He continues: "the infinitive is now a purely verbal form. It cannot be preceded by the definite or indefinite article, an adjective, or a genitive, and positively by the fact that it can take an object and an adverb, and that it possesses a perfect and a passive" (p. 329). He adds that the infinitive can stand as a subject or an object.

Several ESL grammar texts were reviewed to determine how gerundial and infinitival constructions were presented. The majority of the texts merely give lists of verbs which take the gerund, verbs which take the infinitive, or verbs which take either complement. The writers choose verbs they assume to be the most frequently used by native speakers. Almost all of the texts are syntactically based with emphasis on explicit instruction focusing on the form. Of the grammar texts reviewed, only two authors hinted at parts of the Bolinger principle. Frank (1972) states that "most 
infinitive objects have future reference in relation to the time of the main verb" (p. 334). Kirn and Darcy (1985) state that many common verbs which appear before the infinitive have non-action meanings (p. 170). In textbooks copyrighted from 1972 to 1981 little attention is paid to content. The drills are disconnected sentences used for practice to test students' ability to use the correct form of the complements (Frank, 1972; Dart, 1978; Praninskas, 1975; and Azar, 1981). Those texts copyrighted from 1982 to 1985 are different only by the fact that they are integrated using communication-type activities with contextualized practice (Fingado, 1981; Fingado, 1982; Brinton, 1982; Kirn, 1984; Kirn \& Darcy, 1985; Werner, 1985; Kirn\& Church, 1985). Dialogue-type introductions of the constructions or a question-answer format are utilized. Some texts such as Brinton provide no explicit explanations while others such as Praninskas combine gerunds and participles into one category called "ing forms."

Although the educational trend today has moved away from the grammar-translation method of teaching language to a more functional approach, ESL grammar texts continue to present these grammatical constructions based on a modified version of the grammar-translation method of teaching. Although Bolinger's theory is rule-based, his explanation is semantic in nature. The grammar-translation theory is also 
rule-based, but it is syntactic in nature (Celce-Murcia and McIntosh, 1979, p. 3). The main goal of this theory is to teach the form of language. It assumed that once the forms had been taught, then meaning would follow.

Structural grammarians merely describe when gerunds and infinitives are to be used, but give no explanation as to when one form should be used over another. This is due to the fact that they are descriptive linguists and are interested in describing language, not explaining it. Descriptive or structural linguists, as they were called, were more interested in examining the way language was put together and not in finding ways to account for why language was put together the way it was. They just give long lists to be memorized, and this is where ESL grammar texts have followed suit. Therefore, Bolinger's principle appears as an attractive alternative to teaching these constructions. However, it should be noted that Bolinger's principle applies only to the object position and also only to three-fourths of the verbs in question (see Appendix $\mathrm{N}$ for the remaining one-fourth which do not fit the principle).

\section{Other Researchers}

The Bolinger principle pervades the literature reviewed on gerunds and infinitives. It has been 
complemented by additional research, contradicted in certain aspects, and validated by other researchers. However, of the literature reviewed, no researcher has actually tested Bolinger's theory against the traditional grammarians' approach (as far as this researcher knows).

Kiparsky and Kiparsky (1970) complement Bolinger by another theory with reference to several verbs. The Kiparskys' state that "the choice of complement type is in large measure predictable from a number of basic semantic factors" (p. 345). They divide predicates into two categories-factive and non-factive. Celce-Murcia and Larsen-Freeman (p. 437) summarize it well. Factivity, they say, expresses presupposition, and this presupposition remains the same whether the predicate of the main clause affirms, negates, or questions the complement clause, for example:

John regrets that he told you a lie. John doesn't regret that he told you a lie. Does John regret that he told you a lie?

Therefore, the fact that John told you a lie does not change in spite of the main clause being affirmative, negative, or interrogative. On the other hand, non-factive predicates do not remain constant but undergo predictable changes in presupposition depending on whether the main clause affirms, negates, or questions the complement, for example: 
John claims that he told you a lie. John doesn't claim that he told you a lie. Does John claim that he told you a lie?

In this case, it is not a fact that "John told you a lie" and therefore cannot be presupposed to be so. Kiparsky and Kiparsky claim that only factive predicates take gerundial constructions whereas non-factive predicates take only the infinitive. Their semantic-syntactic parameter is similar to, yet different from Bolinger's according to Celce-Murcia and Larsen-Freeman. Where Bolinger's principle falls short (working for only three-fourths of the verbs), Kiparsky and Kiparsky complement it nicely (Celce-Murcia and Larsen-Freeman, p. 438). However, this does not mean that the Kiparskys' factive verbs necessarily supplement Bolinger's theory.

Kempson and Quirk (1971) did a forced test selection on gerunds and infinitives. They observed that certain linguistic items which appear to be free variants in some environments are capable of contrast in other environments. They hypothesized that these items must contain one or more semantic features which can be regarded as latent, i.e., susceptible of being activated in some contexts and suppressed in others. According to them, if this latency is appropriately activated, the contrast will show up. The following is an example from their test: 
2a) I like

2b) I like

(get up) as soon as the alarm rings. (get up) when the weather is warm.

of the subjects, $36 \%$ chose to get up for 2 a) and getting up for $2 \mathrm{~b})$. Kempson and Quirk proposed that a contrast does exist between the two and can be accounted for in terms of a difference in degree of "fulfillment." With a gerund, the sentence implies a sense of fulfillment and with an infinitive, it implies a lack of fulfillment. Significant results were also found for test items $5 a)$ and $5 b$ ).

5a) He started she objected.

5b) He started an hour.

(speak) but stopped again because (speak) and kept on for more than

Of the subjects, $80 \%$ preferred to speak for $5 \mathrm{a}$ ) and speaking for $5 b)$. Kempson and Quirk claim that the observed polarization reflects a contrast between activity that has been sharply curtailed and activity that has been achieved. A question of validity is raised concerning the above test since a forced selection leaves the subject with no alternative for the second answer. As soon as one answer is given, the second is automatic. Because of this fact, a second test was done using free selection. In this new technique, the informants were given one sentence containing a blank and a choice of two selections with which to complete the sentence. Kempson and Quirk confirmed that similar results were received for the free selection test. Therefore, the work of Kempson and Quirk appears to support 
Bolinger's theory of fulfilled and unfulfilled activity.

Although the work of the Kiparskys and Kempson and Quirk complements Bolinger's hypothesis, Kartunnen describes what he calls "implicative verbs," which appear to contradict Bolinger's principle with regard to certain verbs. Kartunnen (1971, p. 357) noticed that certain verbs taking the infinitive "implied either the truth of their complements (positive implicative verbs) or the falsity of their complements (negative implicative verbs)."

$\begin{array}{ll}\text { POSITIVE IMPLICATIVE } & \text { NEGATIVE IMPLICATIVE } \\ \text { Tedmanaged to get the loan. } & \begin{array}{l}\text { Tom failed to sign the deed. } \\ \text { (implies he got the loan) }\end{array} \\ \text { deed) }\end{array}$

Manage and fail clearly contradict Bolinger's principle since the infinitive is not future, hypothetical, or unfulfilled in the sentences above. If a positive implicative verb is negated, the result is a negative implication. For example, "Ted didn't manage to get the loan" implies he did not get the loan. Also, if a negative implicative verb is negated, it results in a positive implication. For example, "Tom didn't fail to sign the deed" implies that he signed the deed (Celce-Murcia and Larsen-Freeman, p. 438). However, it should be noted that the majority of verbs which do take the infinitive are not implicative and therefore those implicative verbs which contradict Bolinger's principle are relatively few. Two 
implicative verbs which would not contradict Bolinger are remember and forget and these could be retained under his hypothesis. Other implicative verbs could be treated as special exceptions.

When viewed together, the findings of these researchers, the Kiparskys and Kempson and Quirk help to reinforce Bolinger's hypothesis to a certain extent. Several verbs which are not explainable through Bolinger make sense if viewed as factive and non-factive through the Kiparskys' analysis. Then Kartunnen's implicative verbs explain why verbs like manage and fail do not fit Bolinger's principle.

Anderson (1976) conducted a study in which a written multiple choice and translation test on six types of sentential complements in object position was administered to native speakers of Spanish and native speakers of Persian. She hypothesized that to-deletion (e.g. I heard him speak) and possessive + gerund were the most difficult for the students because they are used least in native speaker speech. According to Anderson, it is interesting to note this phenomenon since non-native speakers have this difficulty in using these forms in tests and writing as well. Butoyi (1977) was interested in Anderson's study and did a frequency and usage study of gerunds, infinitives and that clauses also keeping only to the object position. She 
validated Anderson's hypothesis. The to-deletion and possessive + gerund were indeed used with the lowest frequency in speech, at least in her sample. Butoyi qualifies her findings by the fact that the total number of complements means very little considering the total number of words uttered. In other words, although Anderson's hypothesis was validated, the number of words uttered was not enough for her findings to be conclusive.

Rosenweig (1973) developed a strategy for teaching gerunds and infinitives based on the Bolinger principle and on So's (1973) research on gerunds and infinitives. In So's experiment, two semantic principles supported were: 1) Bolinger's hypothesis of potentiality versus reification and 2) an effective or punctual action versus a durative action after sensory verbs. The semantic principle must be cognitively grasped by students before they are able to reproduce it on their own. Rosenweig posits that in order to teach gerunds and infinitives, verbs should first be used which can take only the gerund or only the infinitive. First, the teacher presents verbs that take only gerunds, for example:

$$
\begin{aligned}
& \text { I enjoy skiing. } \\
& * \text { I enjoy to ski. }
\end{aligned}
$$

Enjoyment implies something which has already been done or realized. For that reason, the second sentence is 
ungrammatical because it is illogical to enjoy something which you have never done before.

Secondly, the teacher presents verbs which take only the infinitive, for example:

I want to eat.

*I want eating.

In this case, the second sentence is ungrammatical because you have not yet eaten.

Finally, to go one step further, this principle can also be applied to those verbs which take both forms.

I tried closing the window, but that didn't help. I still felt cold.

I tried to close the window, but I couldn't. It was stuck.

The teacher then explains that in the first sentence even though the window had been closed the person still felt cold. In the second sentence, however, the person tried to close the window but was unable to. So's study demonstrates that native speakers intuitively recognize the semantic difference and therefore use closing in the first sentence and to close in the second sentence, thus validating Bolinger's hypothesis that the infinitive expresses something unfulfilled and the gerund expresses something fulfilled. Six verbs were empirically validated by So: 
remember, forget, try, regret, prefer, and sense.

The work done by those researchers cited above has enhanced the research of Bolinger and given his theory added support. However, not all of the researchers validated Bolinger's hypothesis. But when viewed cohesively, the research contributes to a broader understanding of the subject of gerunds and infinitives. Because of the solid theoretical base laid by those researchers who have supported the Bolinger theory, this study has a firm foundation on which to stand. 


\section{CHAPTER III}

\section{METHOD}

This experiment involved ESL learners in the mid to upper intermediate range. The subjects were divided randomly into an experimental and a control group and given the same pre and posttests. Both groups used the same contextualized materials. The experimental group received the treatment which consisted of learning the Bolinger principle in order to know when to use the gerund as opposed to the infinitive. The control group received regular instruction (practice learning which verbs take the gerund, infinitive, or both). The materials and procedures will be explained in detail.

\section{Subjects}

There were 101 subjects representing 25 different language backgrounds who participated in this study. They were ESI students enrolled in colleges in the Portland metropolitan area. Of the groups involved, $57 \%$ represented the Far East (Iaos, The People's Republic of China, The Philippines, Vietnam, Cambodia, Japan, Korea, Indonesia, 
Thailand, and Taiwan). The second largest group of $28 \%$ represented the Middle East (Saudi Arabia, Lebanon, Turkey, Iran, Jordan, Yemen, Syria, Oman, and Pakistan). The smallest group of $15 \%$ represented a variety of other nationalities (Germany, Colombia, Mexico, Honduras, Peru, Czechoslovakia, Cuba, Somalia, Ethiopia and Hungary).

Due to unavailability of standardized placement scores, students' ability was charted by their pretest scores as well as by the level of texts used in the classes. Fundamentals of English Grammar by B. Azar was used by the mid intermediate levels and Understanding and Using English Grammar by B. Azar and Scenario III by E. Kirn were used by the upper intermediate levels. These measures showed that subjects were comparable at the beginning of the study.

The Bolinger theory is more appropriate for mid to upper intermediate students since it deals with semantics and students of lower levels are not as able to distinguish shades of meaning. Students have to be at the point where their vocabulary is such that they are able to recognize the semantics of verbs, i.e., if they cannot distinguish the difference in meaning between the verb decide and the verb complete, then they are not at the stage where the Bolinger principle will help them. This was the main criterion for selecting subjects in the mid to upper intermediate range. 
On the other hand, this principle only deals with gerunds and infinitives in the object position and more advanced students are already familiar with this structure and have gone beyond to learn the other forms where gerunds and infinitives are used, e.g., the perfect form, negative and passive forms. Therefore, in locating groups, the researcher tried to be selective in choosing the appropriate levels. The groups were selected according to teacher preference. However, the researcher tried to have an equal number of subjects in the experimental and control groups according to mid or upper intermediate level (see Table I).

TABLE I

SUBUECTS DIVIDED ACCORDING TO TEXTS USED

\begin{tabular}{|c|c|c|c|c|}
\hline Leve1 & Experimental Group & Text Used* & Control Group & Text Used* \\
\hline Mid & 30 & FEG & 27 & FEG \\
\hline Upper & 21 & UUE & 23 & UUE/S3 \\
\hline
\end{tabular}

\footnotetext{
*FEG = Fundamentals of English Grammar by B. Azar

UUE = Understanding and Using English Grammar by B. Azar

S3 = Scenario III by E. Rirn
}

A total of seven classes in the Portland metropolitan area was used in this study (see Table II for a group profile). Although the classes were two levels--mid intermediate and upper intermediate, there appeared to be no 
significant difference in pretest scores. Therefore, in the experiment, the groups were compared not according to mid intermediate and upper intermediate but as one level. The researcher was successful in accruing 101 subjects, 51 in the experimental group and 50 in the control group (see Figures 1-4 for a breakdown of the population, age, amount of time in the U.S., and amount of time studying English). These figures show that both groups were also comparable in the four variables mentioned above.

TABLE II

PROFTIE OF EXPERTMENTAL \& CONTROL GROUPS

\begin{tabular}{cccccccc}
\hline $\begin{array}{c}\text { \# of } \\
\text { Subjects }\end{array}$ & $\begin{array}{c}\text { Group } \\
\text { Exp./Ctrl. }\end{array}$ & Leve1 & $\begin{array}{c}\text { Average } \\
\text { Age }\end{array}$ & $\begin{array}{c}\text { Far } \\
\text { East } \%\end{array}$ & $\begin{array}{c}\text { Middle } \\
\text { East \% }\end{array}$ & $\begin{array}{c}\text { Other } \\
\%\end{array}$ & $\begin{array}{c}\text { Text } \\
\text { Used* }\end{array}$ \\
\hline 21 & E & Upper & 26.7 & 71.4 & 19.0 & 9.5 & UUE \\
15 & E & Mid & 21.9 & 53.3 & 46.7 & - & FEG \\
15 & E & Mid & 26.4 & 26.7 & 26.7 & 46.6 & FEG \\
14 & C & Mid & 34.4 & 64.3 & 21.4 & 14.3 & FEG \\
13 & C & Mid & 30.9 & 46.15 & 7.7 & 46.15 & FEG \\
13 & C & Upper & 20.4 & 92.3 & 7.7 & - & UUE \\
10 & C & Upper & 21.1 & 50.0 & 50.0 & - & S3 \\
\hline
\end{tabular}

$* * E=$ Experimental Group

$\mathrm{C}=$ Control Group

* FEG = Fundamentals of English Gramaar by B. Azar

UUE $=$ Understanding and Using English Grammar by B. Azar

S3 = Scenario III by E. Rirn 
Students

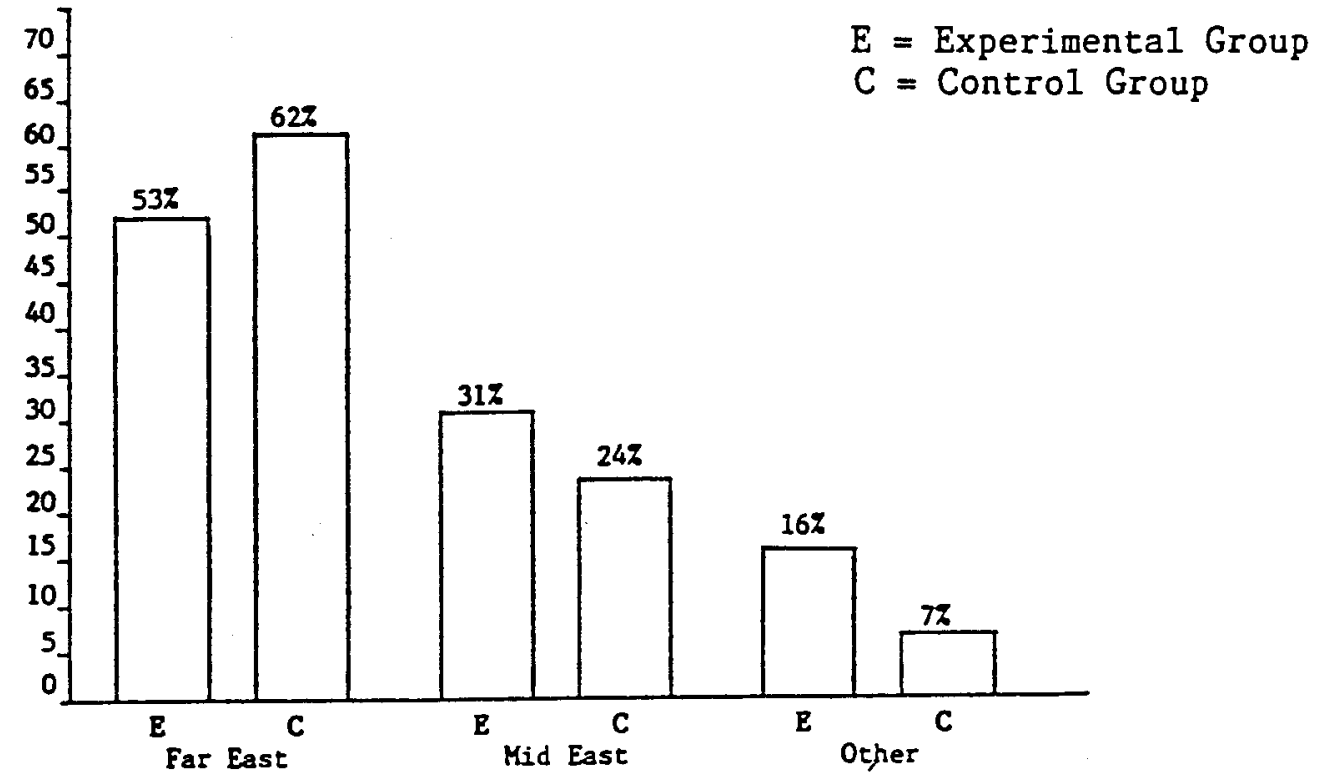

Figure 1. Nationalits spread of experimental \& control groups.

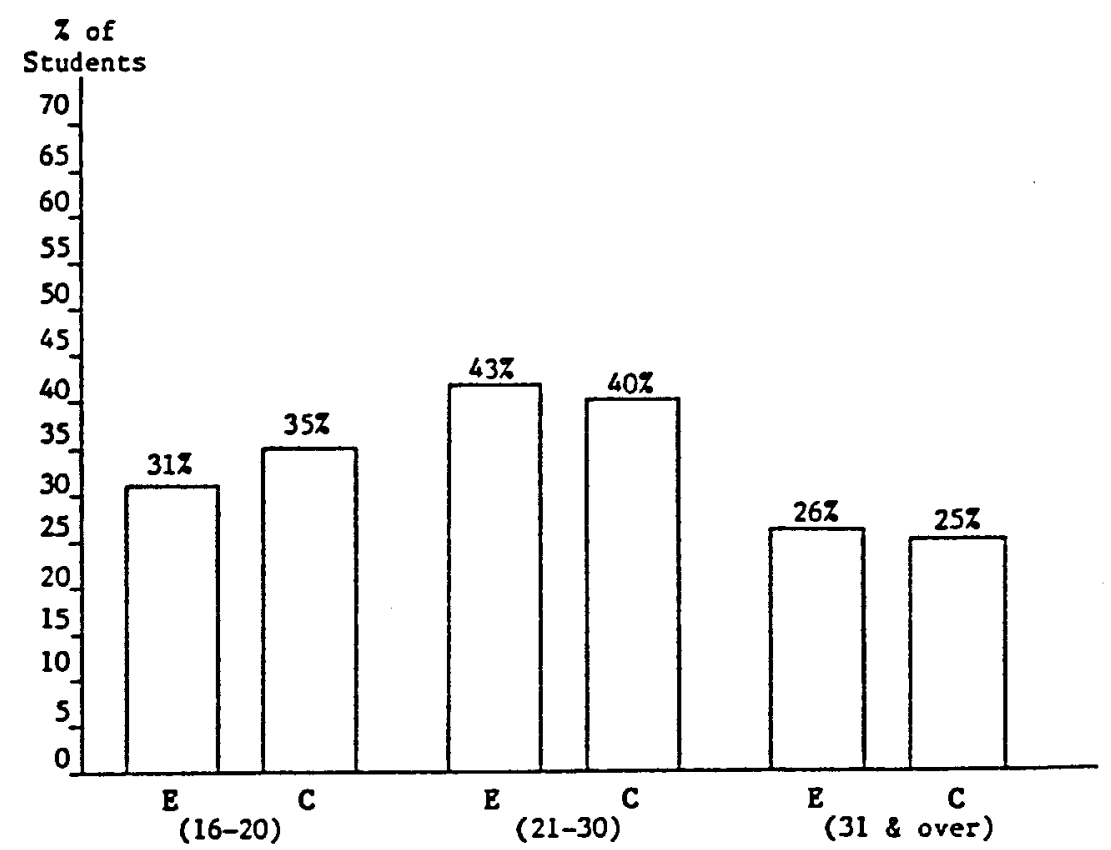

Experimental Mean Age: 25.45 Control Mean Age: 27.25 Median Age: 23 Median Age: 23

Figure 2. Age spread of experimental \& control groups. 


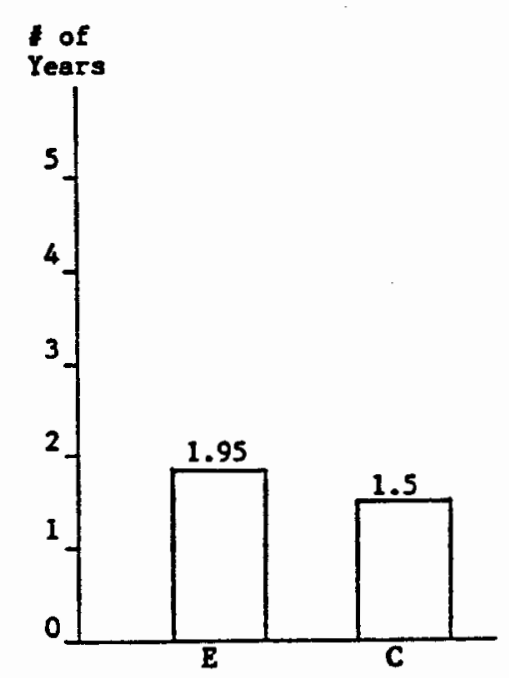

Figure 3. Length of time in U.S.

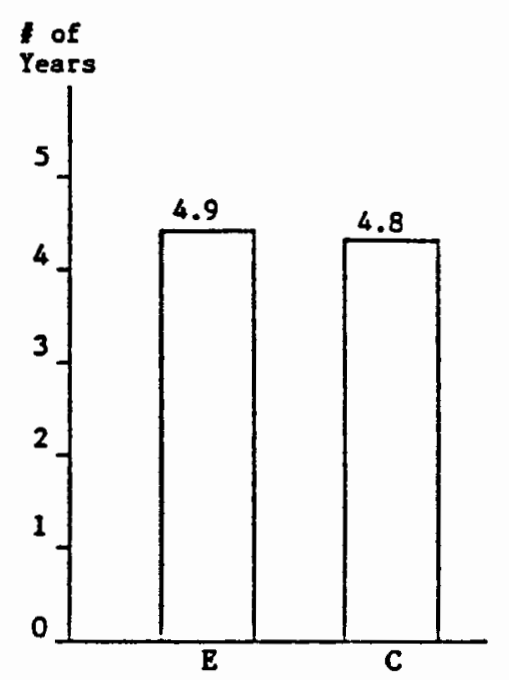

Figure 4. Length of time studying English.

Limitations included availability of students, whether the teachers of the particular classes needed planned to teach gerunds and infinitives, and the type of class, i.e., only grammar or writing classes were involved since the hypotheses included discrete point testing and writing.

\section{Materials and Procedures}

Because this study required participation of other teachers (teachers were not willing to give up more than three teaching hours), the researcher formulated a lesson which took only one 50-minute class period. However, a brief introduction was given after the pretests and a brief review given before the posttests. Since this lesson only included the teaching of gerunds and infinitives in the 
object position, the teachers involved used their respective textbooks to complete the instruction on gerunds and infinitives during subsequent classes.

The researcher was present for all but one of the control groups and noted carefully the teaching strategy of each teacher. The classes were also audio-taped for back-up use. Both the control and experimental groups used the same contextualized materials, the only difference being that the experimental groups received the treatment. The control groups were taught gerunds and infinitives by learning which verbs take the gerund, the infinitive or both forms.

A description of the experimental group lesson is as follows:

A short introduction of gerunds and infinitives was presented after the pretests were administered. It included an explanation of how gerunds and infinitives are formed. Example sentences were presented showing the gerund and infinitive in both subject and object positions and an explanation was given regarding the use of gerunds and infinitives, i.e., as subjects or objects. It was pointed out that these forms were called verbals and were not the main verbs of the sentences but acted as subjects and objects. The present continuous tense was used as an example of what a gerund is not since students often confuse 
gerunds and the present continuous tense.

On the second visit, an entire 50-minute class period was used to present the lesson. A picture of Bruce Springsteen was shown to the classes and the subjects were asked to identify him. This picture was used to try to capture their interest. For the majority who knew Bruce springsteen, it worked. Then a transparency was displayed depicting the life story of Bruce Springsteen (see Appendix A). There were blanks where the subjects were to fill in the appropriate gerunds or infinitives. The researcher then elicited the correct forms of the gerund and infinitive from the subjects. After this was completed, another blank transparency was put on the overhead and three columns were drawn. The first column was labeled Gerunds, the second, Infinitives, and the third Both. The students helped the researcher put the preceding verbs in the correct columns. After this was done, the researcher asked the subjects if they saw any difference in the types of verbs which preceded gerunds and those which preceded infinitives. Then the researcher explained the Bolinger principle in terms appropriate for the level of the students involved. She explained that the verbs which often took the infinitive form were still in the future, still unfulfilled whereas the verbs which took the gerund had already happened, were in progress, often emotive and in some cases involved past 
reference, e.g., the verbs avoid and enjoy. Verbs which took either were to be learned. Due to level of students and time factor, the fine points of when to use a gerund as opposed to an infinitive depending on context was omitted although Bolinger's principle is appropriate in this area as well. After the principle was explained in detail, one of three contextualized exercises was used with the students. They were taken from two texts, English Alive by G. Fingado et $a l$ and The English Connection by G. Fingado et al. (See Appendices B, C, and D). Correct verb forms were elicited from students and if they had difficulty with a particular one, they were referred back to the principle. After reviewing it, the students were usually able to tell which form to use. Due to time constraints, this is all that was accomplished during the 50-minute lesson. An exercise was given for homework which comprised the life story of Michael Jackson (see Appendix E). This exercise was developed by the researcher and followed the format of the springsteen story. The homework exercise was also given to the control groups. On the third visit, a short review was conducted using the Michael Jackson homework to emphasize the Bolinger principle prior to administering the posttests.

A description of the control group lesson is as follows:

The control groups received the same contextualized 
lesson as the experimental groups. The teacher was instructed on how to present the lesson. It was then presented in the following manner: The springsteen picture was shown to the classes and subjects asked to identify him. His life story was presented and the subjects filled in the appropriate gerunds and infinitives. After this was done, three columns were drawn on the board or overhead, the first column labeled Gerunds, the second, Infinitives, and the third Both. The subjects helped put the preceding verbs in the correct columns. Then the subjects were told they had to memorize the lists and lists were either distributed to the classes or the subjects were asked to refer to their texts as reference. At this point, one of the three exercises (Appendices $B, C$, and D) was reviewed with the classes. After that, subjects did an exercise requiring only the infinitive, then an exercise requiring only the gerund, and finally an exercise combining them both. These exercises were taken from the subjects' texts. The same Michael Jackson homework was given to these classes.

Description of the Tests:

There was a series of three pretests and three similar posttests which took another two 50-minute class periods. The first pretest, labeled Discrete Point test (see Appendix F) consisted of 20 fill-in-the blank sentences. Instructions and examples were read aloud by the teachers 
and were also provided in writing. It was pointed out that only one type of verb form should be used per blank. Examples of both verb forms were provided at the beginning of the test. Of the 20 questions, 10 required an infinitive and 10 required a gerund. All the preceding verbs were compatible with the Bolinger principle and there were no instances where either verb form was possible. The time allotted for this test was 10 minutes or until all were finished. No one went over 15 minutes (see Appendix G for a chart of preceding verbs used).

The second pretest, labeled Sentence Combining Test, (see Appendix $H$ ) was an adaptation of the Davidson Ability to Subordinate Test. It was a 20 point test consisting of two sentences in each question. The subjects were asked to combine the two sentences using either the gerund or infinitive form of the verb. As with the Discrete Point test, the verbs used were compatible with the Bolinger principle with 10 questions requiring the gerund form and 10 requiring the infinitive. This test was more powerful than the Discrete Point test in that it tested subjects' ability to combine two sentences using gerunds and infinitives. Because this test was more difficult, the students were given 15 minutes (or until finished) in which to complete the test. As with the other pretests, the directions were read aloud by the teacher and were also provided at the 
beginning of the test with two examples using both forms (see Appendix I for a chart of preceding verbs used).

The third pretest, labeled Writing Sample test was a free writing test. The topic was "Write about your hobbies. Think of several hobbies that you enjoy. What do you do? Where? When? Why? Mention some interesting experiences." The subjects were asked to write for 15 minutes. This topic had been tried out on a different group of ESL students and elicited the use of gerunds and infinitives.

The three posttests were closely related to the pretests but were not the same due to the fact that the time between the two sets of tests was within a one to two week period and the researcher wanted to make sure that confounding was prohibited as much as possible, i.e., the tests were different to prevent subjects remembering the questions from the pretests. Had the pre and posttests been the same, the results might have been distorted or confounded.

The Discrete Point posttest (see Appendix J) tested the same structures as the Discrete Point pretest except the wording was changed to minimize threat to validity, i.e., the structures were retained but the vocabulary was varied (see Appendix $K$ for a list of preceding verbs used). 
The Sentence Combining posttest (see Appendix L) was similar in nature to the Sentence Combining pretest but like the Discrete Point test, the wording was changed for the same reason. This was administered after both experimental and control groups were taught gerunds and infinitives. As with the pretests, directions were given orally as well as written at the beginning of the test, with examples of both verb forms (see Appendix $M$ for a list of all preceding verbs used) .

For the most part, identical preceding verbs were not used for both pre and posttests (see Appendices G, I, K, and M). Since the researcher was seeking to test the Bolinger principle and not the same preceding verbs, it was not deemed necessary to have exactly the same verbs for both pre and postests. Therefore, in writing up the tests, a variety of preceding verbs was selected.

The Writing Sample posttest was another writing test. The subjects were asked to write on a similar topic for 15 minutes. The topic was "Write about your spare time activities. Think of several spare time (free time) activities that you enjoy. What do you do? When? Where? Why? Mention some interesting experiences." This topic was tested on a different group of ESL students prior to this study and also elicited gerunds and infinitives. 
The writing samples were analyzed in the following ways: The number of words written per paper was counted. Then the number of correct and incorrect gerunds and infinitives used in the object position was charted. Other positions where gerunds and infinitives were used were not taken into consideration. For example, 10 gerunds and infinitives may have been used in a paper, but only those in the object position were recorded, thus lowering the original number. The difference in correct usage as well as the number of gerunds and infinitives between the pretest and posttest were then used to determine improvement.

Because some of the vocabulary in the tests was difficult, e.g., words like admit, dread, resent, and hubcaps, the teachers were allowed to explain the meanings so as not to tamper with what was actually being tested. This was true in all cases.

Before launching into the actual study with the experimental and control groups, the researcher conducted a pilot study with a group of non-native residents who were labeled as Intermediate 1 in a 3 level program at Portland State University. This group represented a mid to upper intermediate level of English language proficiency. Several problems came to light after this pilot study was done which influenced the course of this experiment. 
The major problem involved the pre and posttests since they were developed by the researcher. After being piloted, instances of ambiguity appeared which were not apparent prior to the testing. Several questions were revised but there was not sufficient time to pilot these tests again; hence other problem questions surfaced. These are discussed in the Limitations section of Chapter $V$. After examining the results of the writing samples, other writing tasks were researched for better results. Two new writing tasks were piloted with another group of ESL students and found to be more conducive to eliciting gerunds and infinitives in free variation. These writing tasks were then adopted. The second area dealt with the Discrete Point and Sentence Combining tests. After examining the results of these tests, several questions were taken out either because they were too easy or because they were ambiguous. If all the students got a particular question right, the question was omitted. This occurred in only one instance. However, questions which students did poorly on were retained so as not to bias the testing.

Instruments

The tests were criterion-referenced and hence, reliability is questionable. There are also several threats 
to validity. The first threat has to do with the fact that the time difference between the pre and posttests was less than two weeks. In language teaching, it is not feasible to spend more time on these grammatical structures since there are so many other points to cover. One thing which was taken into consideration was the fact that the pre and posttests were worded differently even though the same structures were tested. This was to prevent confounding as much as possible. The second threat has to do with the history factor. It is impossible to determine what the subjects had already learned and what they may have retained from previous language learning classes.

Content validity was high because the tests specifically measured the subjects' knowledge of gerunds and infinitives in both the pre and posttests. The writing sample questions were piloted to see whether gerunds and infinitives would be generated. Construct validity was high since the subject dealt with testing a particular theory which was formulated in 1968 and continues to be advocated by present day linguists (Celce-Murcia and Larsen-Freeman, $1983)$. 
Summary

This chapter covered the method used in accomplishing this experiment. The subjects selected from the Portland metropolitan area were of a mid to upper intermediate level. After selection was accomplished, the subjects were randomly placed in either the experimental or control group. The same three pre and posttests were administered to both groups. These tests were described accordingly. Both groups used identical materials lexercises and homework). However, the experimental group was taught gerunds and infinitives using the Bolinger principle and the control group was taught gerunds and infinitives using list memorization. Since the tests were criterion-referenced, reliability was questionable. However, content and construct validity were high. 


\section{CHAPTER IV}

\section{RESULTS}

The results of this experiment will be stated. This chapter will also include the data analysis utilized. For the discrete point and sentence combining tests, t-tests were used to check for any difference between pre and posttests. The results of these statistical tests will be stated. Since the writing samples could not be statistically analyzed, the results will be descriptively analyzed.

Results of the Discrete Point Tests

The discrete point tests (both pre and post) included 20 questions. The subjects were required to fill in the blanks choosing either the gerund or infinitive of the base form of the verbs in parentheses.

A two-tailed t-test for independent groups was performed to access the difference between the experimental and control groups. A probability factor of $<.05$ was set. This t-test was performed on the improvement scores of the 
Discrete Point test. The $T$ value was 2.73 , the probability factor was <.0075, and degrees of freedom were 99. Based on the $T$ value, the improvement for the experimental group was significantly greater for the Discrete Point test. (Table III shows the mean scores of these tests.)

TABLE III

SCORES OF THE DISCRETE POINT TESTS

\begin{tabular}{lcccccc}
\hline & $\begin{array}{c}\text { Mean Score of } \\
\text { Pretest }\end{array}$ & $\begin{array}{c}\text { Mean Score of } \\
\text { Posttest }\end{array}$ & $\begin{array}{c}\text { Diff. } \\
\text { Difference }\end{array}$ & $\begin{array}{c}\text { Median of } \\
\text { Difference }\end{array}$ & $\begin{array}{c}\text { SDEV of } \\
\text { Difference }\end{array}$ \\
\hline $\begin{array}{l}\text { Experimental } \\
\text { Group }\end{array}$ & 13.39 & 15.76 & 2.37 & 2.37 & 2 & 2.94 \\
$\begin{array}{l}\text { Control } \\
\text { Group }\end{array}$ & 12.34 & 13.0 & .66 & .66 & 1 & 3.36 \\
Difference & 1.05 & 2.76 & 1.71 & & & \\
\hline
\end{tabular}

Experimental Group: \% of Inprovement $=11.85 \%$

Control Group: $\quad \%$ of Improverent $=3.30 \%$

Since the above t-test showed such a significant difference when independent data were used, the researcher decided to check these results using a one-tailed t-test with paired data (subjects' scores on pre and posttests were analyzed against each other) on the Discrete Point pre and posttest to see if there would be similar results. 
The following $\mathrm{T}$ values and $\mathrm{P}$ values were obtained:

Experimental Group

$$
\begin{aligned}
& \mathrm{T}=-5.76 \\
& \mathrm{P}=0
\end{aligned}
$$

\section{Control Group}

$$
\begin{aligned}
& T=-1.39 \\
& P=08557
\end{aligned}
$$

These values indicated that there was indeed a significant difference between the pre and posttest scores for the experimental group. However, at the .05 level of significance, there is not sufficient evidence to indicate that the pretest scores were significantly less than the posttest scores for the control group. This one-tailed t-test with paired data was not performed on the second set of tests since it was obvious that the results would be similar.

The mean score of the Discrete Point pretest for the experimental group was $67 \%$ and for the control group it was 62\%. The experimental group showed a $12 \%$ gain and the control group a $3 \frac{8}{8}$ gain in the posttest (see Figure 10). Since the experimental group in the Discrete Point pretest was 5\% higher than the control group, a Mann-Whitney $U$ test was performed on a representative sample to determine whether the difference was significant. It proved to be insignificant. Also, having two discrete point pretests allowed for some flexibility. 


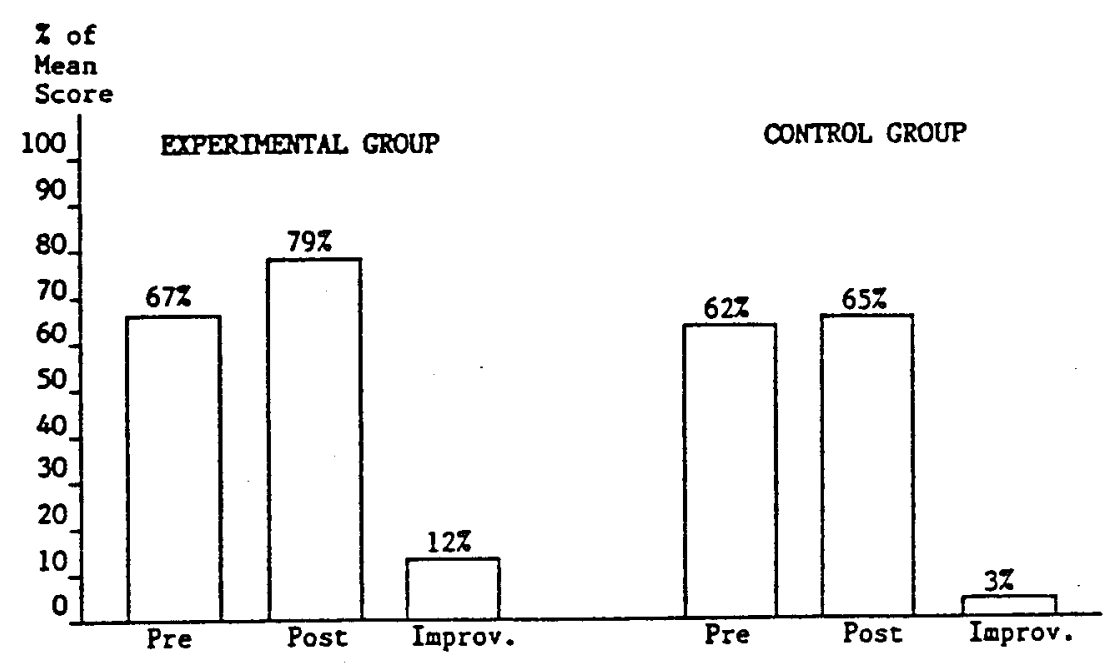

Figure 10. Percentage of mean score for the discrete point tests.

Results of the Sentence Combining Tests

The Sentence Combining tests consisted of 20 questions, with each question containing two sentences. The subjects were asked to then combine the two sentences using either the gerund or infinitive form of the verb. The experimental group scored an average of $50 \%$ on the pretest and the control group scored 50.30\%. The improvement percentage for the experimental group was 228 and was $8.30 \%$ for the control group (see Figure 11).

A two-tailed t-test for independent groups was performed to access any differences between the two groups. A probability factor of $<.05$ was set. The $T$ value was 4.21 , the $P$ value was $<.000056$ and degrees of freedom were 99. These values were exceptionally high and therefore reflected 
a very significant improvement in the experimental group. (For mean scores of these tests see Table IV.)

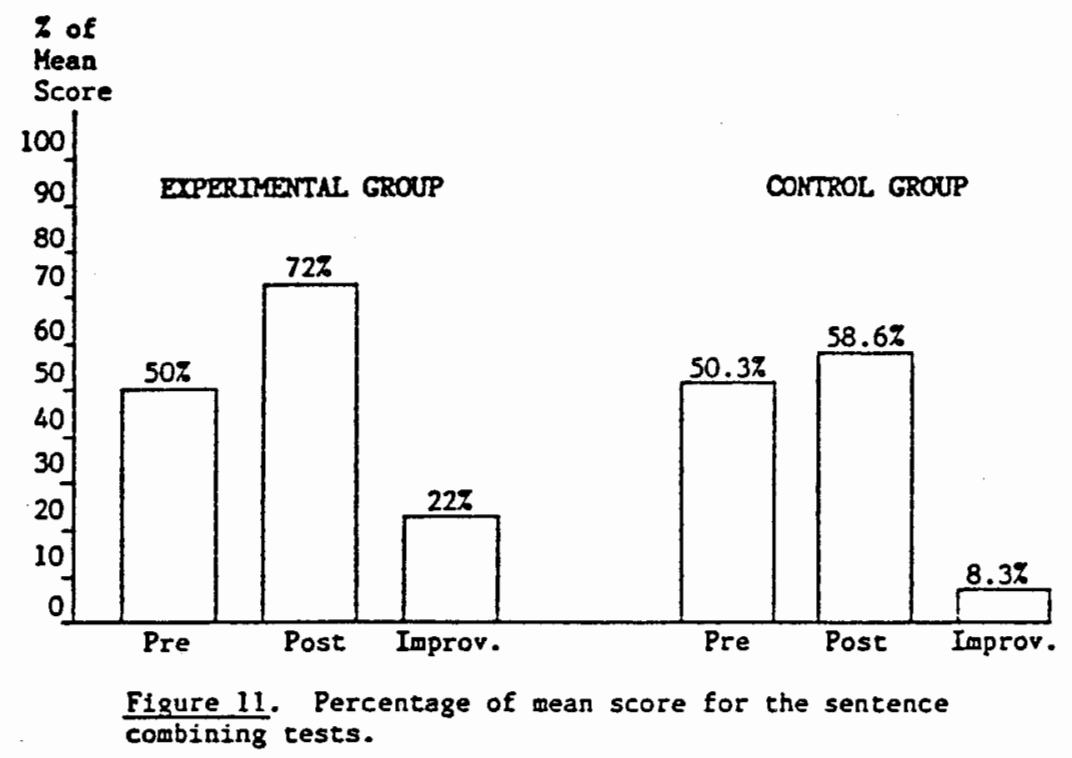

TABLE IV

SCORES OF THE SENTENCE COMBINING TESTS

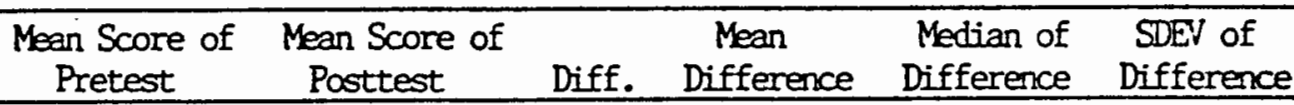

Experimental

Group

10.00

14.49

4.49

4.49

4

3.78

Control

Group

10.06

11.72

1.66

1.66

1

2.90

Difference

$$
.06
$$

$2 . \pi$

2.83

Experimental Group: \% of Improvement $=22.45 \%$

Control Group: $\quad \%$ of Improvenent $=8.30 \%$ 
Results of the Writing Sample Tests

Two similar writing tests were chosen after being piloted in other ESI classes. The first writing sample was "Write about your hobbies. Think of several hobbies that you enjoy. What do you do? Where? When? Why? Mention some interesting experiences." The second writing sample was "Write about your spare time activities. Think of several spare time (free time) activities that you enjoy. What do you do? When? Where? Why? Mention some interesting experiences." Subjects were given 15 minutes in which to write.

The total number of words written were counted. Also, only gerunds and infinitives in the object position were charted. These included both correct and incorrect usage. The amount of writing per paper for both groups was similar, both using many more infinitives than gerunds in the pretest. However, in the posttest, the ratio of gerunds to infinitives was almost 1:1. Gerunds were used almost twice as much in the posttest than in the pretest for both groups (see Figure 5).

The average amount of words for the experimental group was 91. For the pretest, the number of words generated per paper ranged from as high as 187 words to as low as 20 
words. For the posttest, the highest number of words written vas 195 and the lowest 42 .

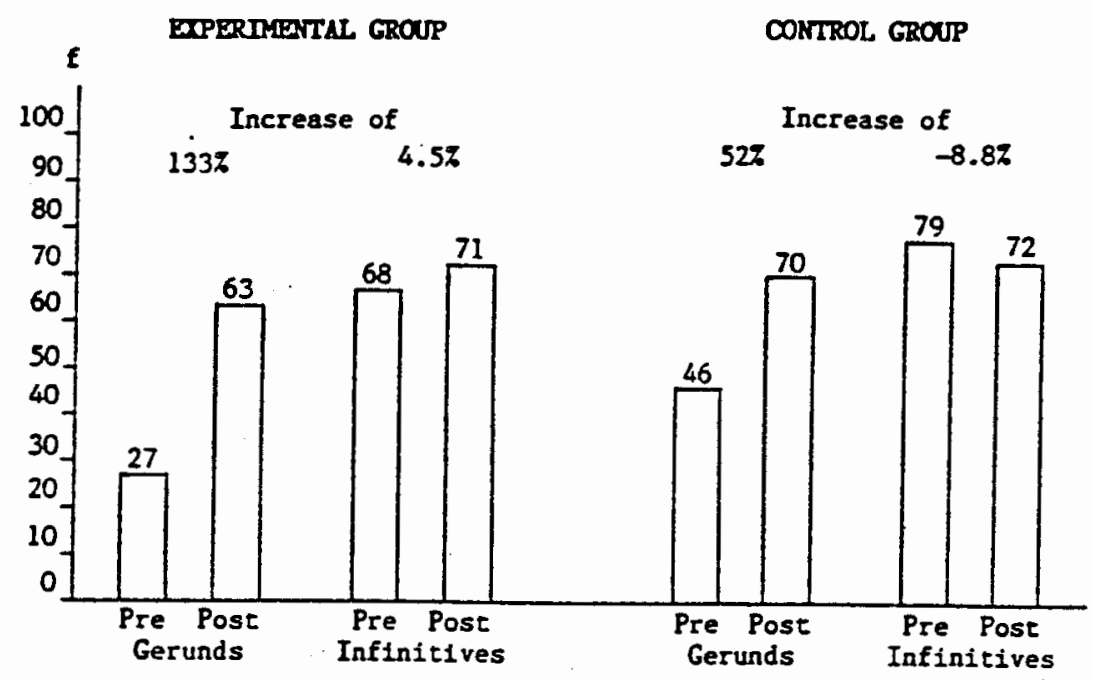

Figure 5. Correct usage of gerunds \& Infinitives.

The writing sample of the experimental group showed a total usage (correct and incorrect gerunds and infinitives) of 2.6:100. In the post Writing Sample, the experimental group showed an improvement of $.43: 100$ (see Figure 6). This portrayed a 16.548 increase.

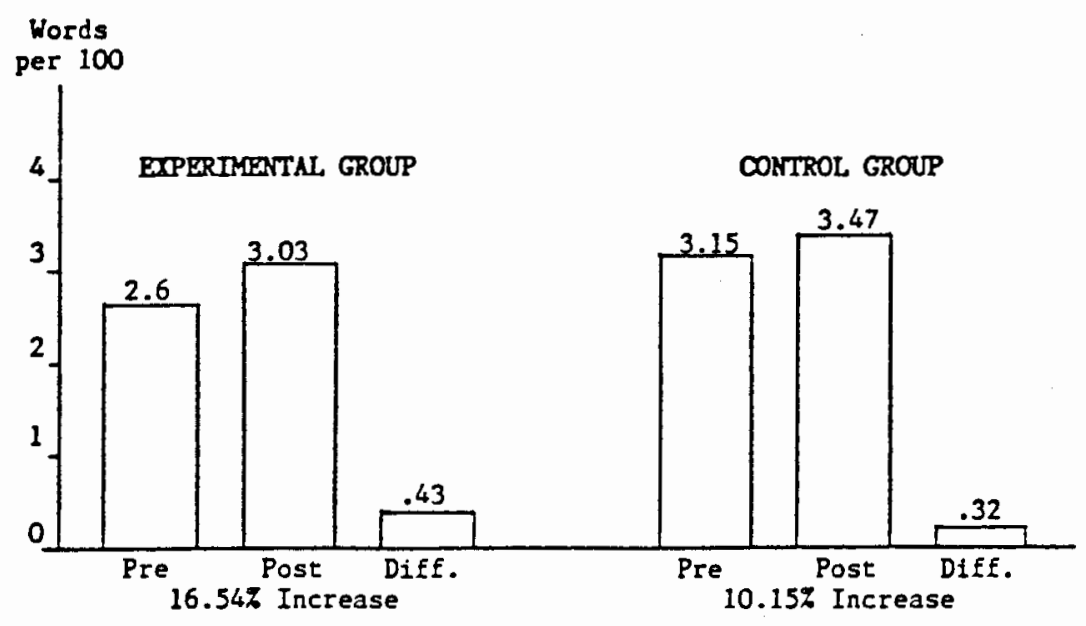

Figure 6. Ratio of total usage of gerunds \& infinitivies. 
The experimental group in the Writing Sample pretest showed a 2.33:100 of correct usage of gerunds and infinitives. In the posttest they increased .47:100 showing an increase of $20.17 z$ (see Figure 7). In looking at the ratio of incorrect to correct usage, the experimental group showed a decrease of 338 (see Figure 8 ). The ratio of incorrect usage of gerunds and infinitives to the number of words written in the posttest showed a $14.81 \%$ decrease for the experimental group (see Figure 9). Therefore, the decrease in incorrect usage was proportionately similar to the increase in correct usage.

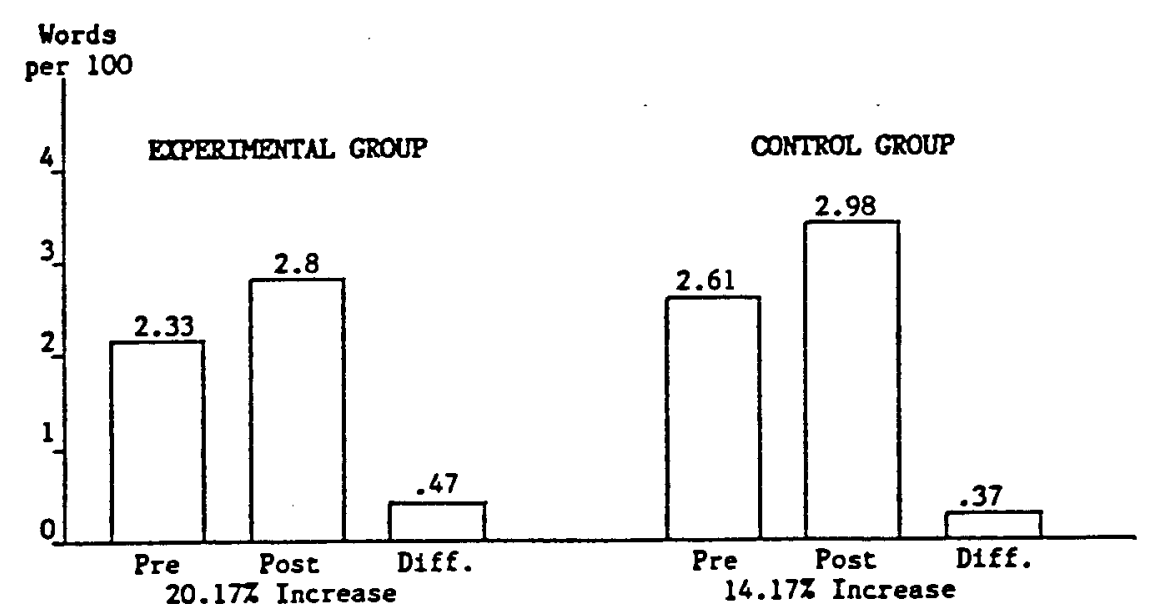

F1gure 7. Ratio of correct usage of gerunds \& infinttives.

The control group showed an average of 95 words written per paper with a high of 219 words written and a low of 21 in the pretest. For the posttest, the highest number of words written was 186 and the lowest 30. The Writing 


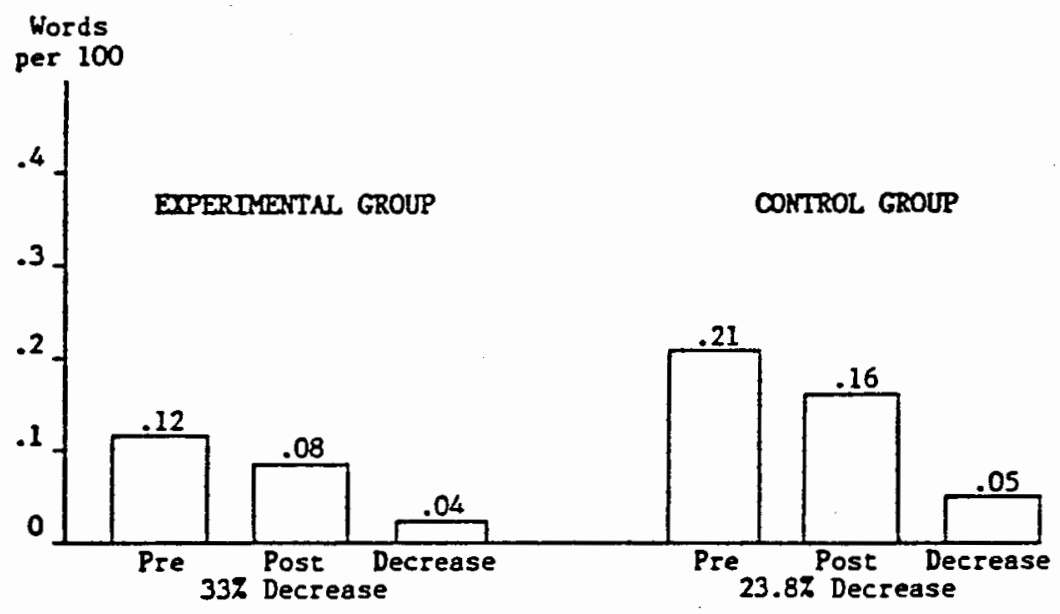

Figure 8. Ratio of incorrect to correct usage of gerunds $\&$ infinitives.

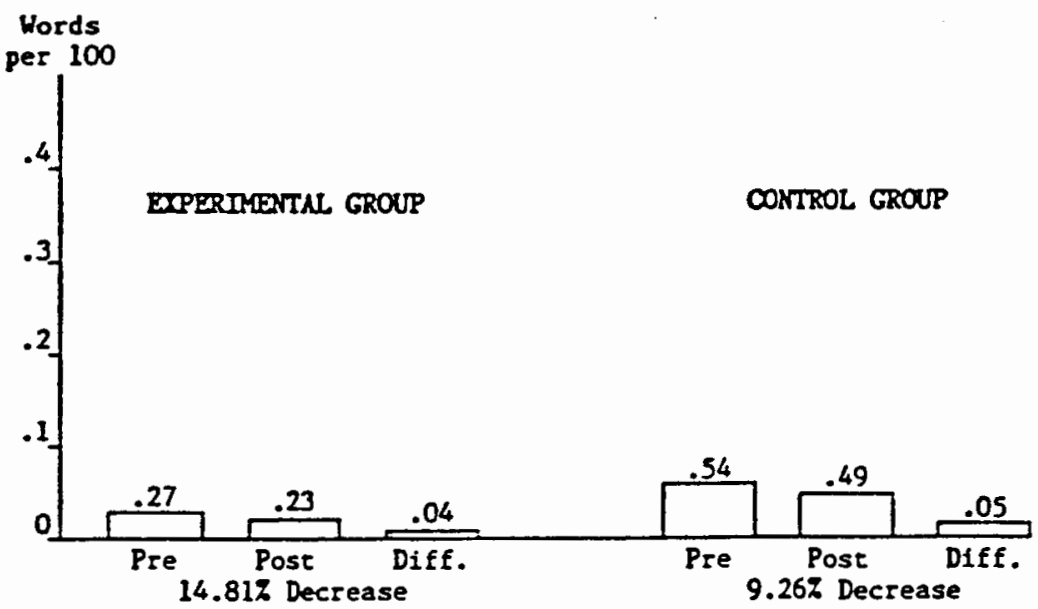

Figure 9. Ratio of incorrect usage of gerunds \& infinitives to amount of vord witten. 
Sample pretest showed a total usage lcorrect and incorrect gerunds and infinitives) of 3.15:100. In the post writing Sample, they showed a .32:100 improvement, .11 less than the experimental group (see Figure 6). Nevertheless, their increase was $10.15 \%$. With regard to correct usage of gerunds and infinitives, the pretest showed a ratio of 2.61:100. For the posttest, there was an increase of $.37: 100$. This was a 14.178 increase over the pretest (see Figure 7 ). The ratio of incorrect to correct usage showed a decrease of $23.8 \%$ (see Figure 8 ). The ratio of incorrect usage of gerunds and infinitives to the number of words written in the posttest showed a $9.26 \%$ decrease (see Figure 9). Like the experimental group, the decrease in incorrect usage was proportionately similar to the increase in correct usage. (See Table $\mathrm{V}$ for comprehensive results of the Writing Sample tests.)

TABLE V

RESULTS OF THE WRITING SAMPLE TESTS

\begin{tabular}{lccc|ccc}
\hline & \multicolumn{3}{c|}{ EXPERIMENTAL GROUP } & \multicolumn{3}{c}{ CONTROL GROUP } \\
\hline & \multicolumn{2}{c}{$\begin{array}{l}\text { Total } \\
\text { Ratio }\end{array}$} & Correct & Incorrect & \multicolumn{1}{c}{ Total } \\
Ratio & Correct & Incorrect \\
\hline Pretest & $2.6: 100$ & $2.33: 100$ & $.27: 100$ & $3: 15: 100$ & $2.61: 100$ & $.54: 100$ \\
Posttest & $3.03: 100$ & $2.8: 100$ & $.23: 100$ & $3.47: 100$ & $2.98: 100$ & $.49: 100$ \\
Difference & $.43: 100$ & $.47: 100$ & $.04: 100$ & $.32: 100$ & $.37: 100$ & $.05: 100$ \\
\cline { 2 - 7 } $\begin{array}{l}\text { \% of } \\
\text { Improv. }\end{array}$ & \multicolumn{2}{c|}{ Increase } & Decrease & Increase & Decrease \\
\cline { 2 - 7 } & $16.54 \%$ & $20.17 \%$ & $14.81 \%$ & $10.15 \%$ & $14.17 \%$ & $9.26 \%$
\end{tabular}


Summary

The results obtained for all the tests were stated in this chapter. The Discrete Point tests showed a significant improvement in the experimental group over the control group. The results of the sentence Combining tests were even more significant than the Discrete point tests. Finally, although the writing Sample tests were not run through any statistical test, the experimental group again showed a better improvement than the control group in their correct usage of gerunds and infinitives. 


\section{CHAPTER V}

\section{CONCLUSIONS AND RECOMMENDATIONS}

This chapter will seek to put this study into perspective. The hypotheses will be restated and test results will be discussed. Once the results have been discussed, implications will be drawn. Limitations will be noted and documented. Finally, suggestions for further research will be made.

The first hypothesis is as follows:

Teaching ESL learners gerunds and infinitives using the Bolinger principle will result in significant improvement in their ability to use gerunds and infinitives in discrete point tests.

The results of the t-tests performed on the Discrete Point and Sentence Combining tests showed that the experimental group did significantly better on the posttests than did the control group, thus validating the first hypothesis. This principle, once cognitively grasped by the experimental group was useful in helping them determine when to use the gerund as opposed to the infinitive. The researcher was, however, surprised at the significant 
improvement of the experimental group given the fact that the length of time involved in this experiment was extremely limited and one of the major tenets of language learning is reinforcement over a period of time. The results, therefore, should not be viewed as conclusive since the passing of time may affect the findings.

Since the experimental group in the Discrete Point pretest scored 5\% higher than the control group, a Mann-Whitney $U$ test was performed on a representative sample to determine whether the difference was significant. It proved to be insignificant. Also, having two similar pretests allowed for some flexibility. The control group doing . 3\% better than the experimental group on the sentence Combining pretest balanced the two groups or at least showed that they were of comparable levels.

Although the Discrete Point pretest was easier for the subjects (mean of approximately 64.5\%), their improvement was not as great as for the second test. Scores on the Sentence Combining pretest for both groups were lower than the first test by $14.5 \%$ but the increase in improvement after the posttest was $22 \%$ for the experimental group and $8.3 \%$ for the control group. One reason could have been that the test questions were contextualized and therefore semantically the subjects were able to infer more correctly (see Figures 10 and 11, pp. 39-40). 
The control group received the identical teaching materials but were drilled using lists of verbs and were told they had to memorize the lists. There is no guarantee that these subjects indeed memorized the lists, given the short time period involved. Just from this viewpoint alone, it would seem that given the choice to memorize one short principle (which would then help students in selecting the correct form) as opposed to a long list of verbs that the former would be preferable.

It would then appear to be useful for teachers to use the Bolinger principle in their presentation of gerunds and infinitives, as well as using the lists for back-up use. Even though a few limitations have been discussed, the results of the tests cannot be denied. The use of the Bolinger principle did show a marked improvement in the experimental group over the control group, and therefore, the first hypothesis was validated.

The second hypothesis is as follows:

Teaching ESL learners gerunds and infinitives using the Bolinger principle will result in significant improvement in their use of gerunds and infinitives in their writing.

With regard to the Writing sample tests, the 
experimental group again showed a better improvement in correct usage of gerunds and infinitives. However, the control group also showed some improvement (see Table V, p. 45). It should also be noted that since subjects could select their own gerunds and infinitives, they most likely chose those they felt confident with and hence, fewer errors overall were made. Also, not only did both groups increase in correct usage but they also decreased in incorrect usage. However, the experimental group again, did slightly better (see Figures 8 and 9, p. 44).

Since the Writing Sample tests were free writing, the subjects were not restricted in any way. Overall, both groups used more infinitives than gerunds in their writing and this agrees with research that ESL learners pick up those complements that are most frequent in the English language, (Butoyi, 1977) infinitives being more frequent. However, in the posttest the ratio of gerunds to infinitives was almost $1: 1$ (see Figure 5, p. 42). This could be accounted for by the fact that after treatment both groups felt more confident in using more gerunds. Another factor involved the type of test (free writing). Subjects could write as much as they wanted or as little as they wanted. Some wrote as many as 219 words while others exerted little effort. Some of the subjects lacked motivation in writing for 15 minutes during the second writing sample. It could 
have been because the subjects knew this was an experiment and either tried their best or vice versa, the Hawthorne Effect (subjects know that they are selected for an experiment and therefore, try their best) in this case working contrary to fact. It could also have been because of the similarity of topics that the subjects lost interest in the posttest and produced less.

Although the writing tests were worded in such a way as to generate gerunds and infinitives, the topics used the verb enjoy which does generate gerunds rather than infinitives. The researcher therefore checked to see how many preceding verbs were actually used by the subjects. The verb like was actually used more than the verb enjoy. A total of 21 different verbs were used by both groups. (For frequency of verbs used see Table VI.)

Since these papers were relatively short, the number of gerunds and infinitives used seemed to be proportionate to the length. It should be reiterated that only gerunds and infinitives used in the object position were counted and that subjects did use them elsewhere as well. This accounts for the low number of gerunds and infinitives recorded per paper.

Judging from the results of the Writing Sample posttest it would appear that the second hypothesis was also 
TABLE VI

FREQUENCY OF PRECEDING VERBS USED IN THE WRITING SAMPLE TESTS

\begin{tabular}{|c|c|c|c|c|c|c|}
\hline Verb & $\begin{array}{c}\text { Pretest } \\
\text { Exp. } \\
\end{array}$ & $\begin{array}{c}\text { Posttest } \\
\text { Exp. }\end{array}$ & $\begin{array}{l}\text { Pretest } \\
\text { Control } \\
\end{array}$ & $\begin{array}{r}\text { Posttest } \\
\text { Control } \\
\end{array}$ & Total & Percent \\
\hline like & 27 & 32 & 33 & 23 & 115 & 34.3 \\
\hline enjoy & 11 & 20 & 16 & 23 & 70 & 20.9 \\
\hline would like & 9 & 5 & 10 & 8 & 32 & 9.5 \\
\hline want & 3 & 5 & 8 & 12 & 28 & 8.4 \\
\hline go & 3 & 8 & 3 & 10 & 24 & 7.1 \\
\hline start & 3 & 4 & 2 & 5 & 14 & 4.2 \\
\hline $\operatorname{try}$ & 2 & 6 & - & 5 & 13 & 3.9 \\
\hline Iove & 3 & 5 & 3 & 2 & 13 & 3.9 \\
\hline decide & - & 1 & 2 & 2 & 5 & 1.5 \\
\hline prefer & 1 & 1 & 1 & 1 & 4 & 1.2 \\
\hline begin & 2 & - & 1 & 1 & 4 & 1.2 \\
\hline hate & 1 & 2 & - & - & 3 & .9 \\
\hline keep. & 2 & - & - & - & 2 & .6 \\
\hline hope & - & 1 & - & - & 1 & .3 \\
\hline know & - & 1 & - & - & 1 & .3 \\
\hline forget & - & - & 1 & - & 1 & .3 \\
\hline wish & - & - & 1 & - & 1 & .3 \\
\hline look forward to & - & - & - & 1 & 1 & .3 \\
\hline stop & - & - & - & 1 & 1 & .3 \\
\hline spend & - & - & - & 1 & 1 & .3 \\
\hline promise & - & - & - & 1 & 1 & .3 \\
\hline TOTAL & 67 & 91 & 81 & 106 & 335 & \\
\hline
\end{tabular}

NOTE: These numbers do not represent total times used, but the number of subjects who used them. 
supported. The experimental group did show a $20.17 \%$ improvement in correct usage of gerunds and infinitives and the control group showed a 14.17\% improvement (see Figure 7, p. 43). However; the results cannot be deemed as conclusive since the number of words written per paper was relatively short for both groups.

\section{Limitations}

Limitations to this study included first of all the fact that it is extremely difficult to obtain a guaranteed random sampling thereby violating the major rule of a true experimental design. Secondly, a larger sample generates more valid results and although 101 subjects were adequate, the original 134 would have been even better. Due to varying circumstances, 33 subjects were disqualified, e.g., showing up for one test or tests but not for the others, absence, illness, etc.

Another limitation involved the actual tests. Although the tests were piloted in a previous study and several changes were made, there were still several questions which caused difficulty to the majority of subjects. These could be changed to further improve the tests. The following are the problem questions: 
The Discrete Point pretest (see Appendix F) appeared to be within the ability level of the subjects. Only one question posed a problem for almost all subjects (both experimental and control groups). Approximately 96\% missed this question.

18. Many Portland residents resent paying (pay) high property taxes.

However, this particular question did not show any major syntactical differences from the other questions. The only other problems could have been the vocabulary and usage of resent. The word resent may have been new to the majority of the subjects but as stated earlier, if subjects did not recognize a word they were allowed to ask the proctor.

Besides question \#18, the second most difficult question was question \#1, which approximately $70 \%$ of the subjects missed. This was a $26 \%$ difference compared to question \#18 and the question did not appear to be misleading or confusing.

1. The defendant admitted stealing (steal) the car.

One problem again could have been the vocabulary but subjects were allowed to ask for clarification. The rest of the questions missed showed a gradual decline beginning at $67 \%$ missed and ending at $17 \%$. 
The Discrete Point posttest (see Appendix I) showed no apparent irregularities. Question \#7 was missed by $55 \%$ of the subjects but this question did not appear to be noticeably different from the other questions.

7. Gary denied taking (take) the last piece of pie but his mother didn't believe him.

The rest of the questions missed ranged from $54 \%$ to $7 \%$.

The Discrete Point posttest (see Appendix H) which involved combining two sentences into one sentence, using either gerunds or infinitives, was a more difficult test overall. Of the four discrete point tests (two pretests and two posttests) the subjects did the worst on the sentence Combining pretest. One reason could have been the type of test it was, i.e., sentence combining. Another reason could have been that some of the questions may have appeared confusing and only subjects with a greater command of syntax could have figured them out.

The first question which appeared to be confusing to the subjects was question \#6.

6. a. John was accused of drunk driving.

b. He denied it. John denied driving under the influence of alcohol.

The majority of subjects used the verb accuse instead of driving since driving was not clearly stated in the 
sentence.

The second question which posed a problem was question $\# 1$.

1. a. Portland residents pay high property taxes.

b. They resent it.

Portland residents resent paying high property taxes.

Although this question caused a problem for the majority of subjects, it was straightforward and showed none of the problems of question \#6.

The third question which caused difficulty for the subjects was question \#8.

8. a. I must work every other weekend.

b. I can't get used to that.

I can't get used to working every other weekend.

The sentences are not syntactically difficult but the problem here which could have proved confusing to the subjects was the preposition to. The subjects may not have known that "get used to" is a phrasal verb and therefore the to is not part of an infinitive form of the verb. The rest of the questions missed ranged from $86 \%$ to $19 \%$. It should be taken into consideration that the pretest scores reflect more subjects than actually ended up in the sample, and, therefore, these scores include 134 subjects as opposed to the posttest scores which reflect only 101 subjects. 
Two questions stand out as problem questions in the Sentence Combining posttest. Question \#3 was missed by $76 \%$ of the subjects.

3. a. Bob was accused of cheating on his test. b. He denied it.

Bob denied cheating on his test.

This question was similar to the Sentence Combining pretest, question \#6 in that the phrases "of drunk driving" and "of cheating" were the cues the subjects needed to focus on and due to syntactic and semantic level of difficulty, it proved difficult and confusing for them. In spite of that fact, however, subjects did $24 \%$ better on the sentence Combining posttest, question $\# 3$ as opposed to the sentence Combining pretest, question \#6.

The second question posing difficulty for $58 \%$ of the subjects was question \#1.

1. a. The boys stole the neighbor's hubcaps.

b. They admitted it. The boys admitted stealing the neighbor's hubcaps.

This question did not appear to have any major problem. The only problem could have been subjects' understanding of the word admit. The rest of the questions missed ranged from $57 \%$ to $8 \%$.

Although some difficulties came to light after the four tests were administered, they did not appear to be 
significant enough to negatively skew the results. Overall, the tests seemed to fit the level of students and did not appear to be overly difficult or overly easy (see Tables II and IV).

Finally, the most significant limitation was the fact that the time involved in the testing and treatment was less than two weeks. Because of this very fact, the pre and posttests were different in order to prevent confounding. As stated previously, grammatical concepts need time and reinforcement to become internalized and although the researcher and other teachers tried to reinforce learning, (using exercises and giving homework) the time factor could not be ignored. Realistically, teachers cannot spend more than one to two lessons on this subject when so much else must be covered in the course of a term.

Further Research

Given time constraints, no researcher is ever able to cover every possible area within one experiment. Therefore, this experiment is by no means conclusive. Another way to test the Bolinger principle for more long term effects would be using a time series experiment. If a teacher had the same class over a period of three to six months, this might shed more light on the reliability of the Bolinger principle 
and produce more enlightening results.

This study only dealt with mid to upper intermediate learners but it might be interesting to use a group of proficient second language learners. A study could be done to see if their writing included the correct usage of gerunds and infinitives or if they avoided these structures. In other words, have these structures been internalized by the time second language learners become proficient?

Another suggestion for further research would be to follow Rosenweig's (1973) teaching strategy utilizing the Bolinger principle and spread out the teaching time to incorporate at least three teaching hours. The first hour could be spent introducing gerunds, the second hour introducing infinitives, and the third hour could include distinguishing stylistic preferences. These preferences are natural for the native speaker but are difficult for a non-native speaker to differentiate. The Bolinger principle would be interwoven into all three sessions. This structure would also allow the subjects further time in which to internalize these grammatical constructions. 
Summary

This experiment was carried out because the researcher wanted to know if using the Bolinger principle would result in any significantly better scores on discrete point tests and writing as opposed to the usual method of list memorization. Any method to minimize tedious learning is helpful to the foreign language learner and this principle appeared to be worth trying out. The results of the tests proved to be significantly in favor of the experimental group. This was further enhanced by the large sample that was used, thus making the results more reliable. Therefore, taking into account the validation of the hypotheses, teachers might be interested in at least trying out this principle in the classroom. Naturally, they would have to be selective in judging which levels would most benefit from this principle.

The results of the testing showed improvement by both the experimental and control groups but with the experimental group doing significantly better on the discrete point tests. Although the results supported the first hypothesis "teaching ESL learners gerunds and infinitives using the Bolinger principle will result in significant improvement in their ability to use gerunds and infinitives in discrete point tests," Iimitations were 
recognized and discussed. In the writing Sample test, the improvement made in usage seems to support the second hypothesis "teaching ESL learners gerunds and infinitives using the Bolinger principle will result in significant improvement in their use of gerunds and infinitives in their writing." However, the tests were not able to be statistically analyzed; therefore, the support is inconclusive. Overall, the experiment was informative, in at least showing that significant improvement is possible when using the Bolinger principle to teach gerunds and infinitives with mid to upper intermediate ESL learners. 


\section{REFERENCES}

Anderson, J. I. (1976). "Comparison of the order of Difficulty of English Sentential Complements Between Native Speakers of Spanish and Native Speakers of Persian." Paper presented at the Los Angeles Second Language Research Forum, UCLA, Feb. 1976.

Azar, Betty Schrampfer. (1985). Fundamentals of English Grammar. Englewood Cliffs, New Jersey: Prentice-Hall.

Azar, Betty Schrampfer. (1981). Understanding and Using English Grammar. Englewood Cliffs, New Jersey: Prentice-Hall.

Brinton, D. \& Neuman, R. (1982). Getting Along: English Grammar and Writing (Bk.2). Englewood Cliffs, New Jersey: Prentice-Hall.

Bolinger, D. (1968). "Entailment and the Meaning of Structures." Glossa 2:2, 119-127.

Butoyi, C. (1978). "The Accuracy Order of Sentential Complements by ESL Learners." Unpublished MA Thesis in TESL, UCLA.

Butoyi, C. (1977). "A Frequency and Usage Study of Gerunds, Infinitives, and That Clauses as Sentential Complements." Unpublished English Paper 215, UCLA, Fall 1977.

Celce-Murcia, M. and McIntosh, L. (1979). Teaching English as a Second or Foreign Language. Rowley, MA.: Newbury House.

Celce-Murcia, M. and Larsen-Freeman, D. (1983). The Grammar Book: An ESL/EFL Teacher's Course. Rowley, MA: Newbury House.

Dart, A. K. (1978). ESL Grammar Workbook 2. London: Prentice-Hall. 
Dunham, H. and Surnmers, C. (1996). English Integrated. Boston: Little, Brown \& Co.

Fingado, Gail and Jerome, Mary. (1982). English Alive. Boston: Little, Brown \& Co.

Fingado, Gail, Freeman, Leslie, et al. (1981). The English Connection. Boston: Little, Brown \& Co.

Frank, Marcella. (1972). Modern English: A Practical

Reference Guide. Englewood Cliffs, New Jersey:

Prentice-Hall.

Jespersen, O. (1966). Essentials of English Grammar.

University, Alabama: University of Alabama Press.

Jespersen, O. (1968). Quoted in Dwight Bolinger "Entailment and the Meaning of Structures." Glossa 2:2, 119-127.

Kartunnen, L. (1971). "Implicative Verbs." Language 47:3, 548-572.

Kempson, R. \& Quirk, R. (1971). "Controlled Activation of Latent Contrast." Language 47:3:548-572.

Kiparsky, P. \& Kiparsky, C. (1970). "Fact," in M. Bierwisch and $K$. Heidolph (eds.), Progress in Linguistics. The Hague: Mouton.

Kirn, Elaine and Jack, Darcy. (1985). Interaction I: A Communicative Grammar. New York: Random House.

Kirn, E. (1984). Scenario 3, English Grammar in Context. New York: Holt, Rinehart, \& Winston.

Kruisinga, E. (1925). A Handbook of Present-Day English, Part III. Groninjern.

Ota, Akira. (1963). "Tense and Aspect of Present-day American English" reviewed by Martin Joos. Language 30, 487-498.

Poutsma, Hendrik. (1929). A Grammar of Late Modern English, Part II. Groninjern.

Praninskas, J. (1975). Rapid Review of English Grammar, 2 ed. Englewood Cliffs, New Jersey: Prentice-Hall. 
Rosenweig, Fred. (1973). "A Strategy for Teaching Gerunds and Infinitives to Advanced ESL Students." Unpublished Eng. 215 paper, UCLA.

So, Nguyen Van. (1973). "The Semantic Interpretation of Infinitives and Gerunds as Sentential Complements." Unpublished M.A. thesis in TESL, UCLA.

Werner, Patricia K. (1985) . Mosaic: A Content-Based Grammar. New York: Random House.

Werner, Patricia K. \& Church, Mary. (1985). Interactions: A Communicative Grammar. New York: Random House. 
APPENDIX A

BRUCE SPRINGSTEEN

He was born in Asbury Park, New Jersey, in 1950.

His parents intended him (be) a doctor.

He wanted (be) a rock and roll musician.

He started (play) the guitar at age 15 .

He practiced (play) every free minute.

He formed his first group in 1970.

At first, people did not like (Iisten) to his music. Bruce kept on (play).

In 1973, he decided to Run." (cut) his third album, "Born

This album was an immediate success.

From then on he continued (become) more popular.

In 1983, he cut another successful album, "Born in the USA."

In the same year, he fell in love with Julianne Phillips.

He gave up (go out) with other girls.

He asked her (marry) him.

She agreed (marry) him.

His marriage has not stopped him from (play). He enjoys (go) on concert tours very much.

But he avoids (accept) too many since he got married. He would like (play) for a long time yet. 
Choose the correct tense for the first verb and put the second verb in the infinitive or the gerund form.

Joe's and Diane's personalities are different in other ways, too. Diane is a very quiet person, bat Joe is very talkative. He $\frac{\text { likes } \text { os tall }}{\text { fikeltelly }}$ all the time.

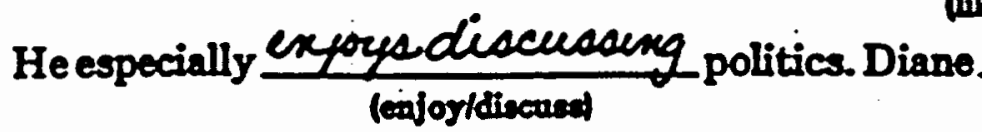

(hateddiscusel politics. Also, when she is tired, she doesn't

(wantralld about anything. she lneodhavel peace and quiet. Joe doesn't understand. When Diane is quiet, he thinks she's unhappy. Sometimes when Joe talks a lot, it drives Diane crazy. Then she jokes and says, "Joe, you never (stophente)

However, Joe and Diane are not completely different. They share some interests, and they lenjog dol many things together. For example, both Joe and Diane are interested Saturdays they fof, in, aboutl lookd $.0 n$ all day

aikelspead looold but they both disher. They also (thate/wash) aized 8 ol toold movies from the 1930s and 40 s together, and they to the theater. aikeleol

They have some problems in their relationship, but in general they together. 
Elvis Presley, the great rock guitarist and singer. was born on Januery 8 , 1935, in Tupelo, Mississippi. His parents liked to take him to church. $\mathrm{He}$ to the church music and (enjoy/listen) (sing)

Elvis was very close to his mother, Gladys. She (negativa, wantbe) out of her sight, so she walked him to school every day until he was a senior in high school.

Elvis a bicycle, but his parents (wanthave) a bicyclo, but his parents him one. Instead they bought him a guitar. Elvis (reluselgive) (practicoplay) the guitar every free moment that he had. He (tryhimitate) music from the radio.

Elvis's mother (encourage/play)
football, but she guitar and sing. Elvis also
she was afraid he would get hurt. She furge/negative, play)
his mother, so he quit playing football. She also
(negative, wantworry)
(forcolquit) a job because she thought it interfered with his school
work. In 1953 Elvis (decide/rocord) his first album. Soon after, disc jockeys Elvis's records on their radio stations. Elvis also sang on (startplay) television on the Ed Sullivan Show, but the TV network Elvis from the waist down because he wiggled his hips so erotically. Elvis earned millions of dollars from his records and movies and (likehear) people call him the "King" of rock "n roll.

In 1976 Elvis's doctors performing because he was (onder/stop) quite sick. In 1977 Elvis died of a heart attack at the age of forty-two. His mother had died at the same age. 


\section{Olroctions}

Choose the correct tonse of the first verb. Croose to fofinitive or the gerund form for the secood rert. There are soone verts in this excencise for which both fufinitive and gerund are correct.

During the summer of 1960 coe of the most important events in the his:loxj of rock mic tock places in Woodstock Now York Arowod half a million people travelod to this scuall lown for a woekend rock music feetival Many more poople clented to Corke but coulde' get noer the area because (riventocen

of all the traflic People Trepertion traffic bectood up for ten miles.

The weether was bad on the weebeod. It rained every day except for the last coes. When the procoters of the concert heard the weather forecast. thes

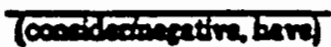
abead with their plans Some people the feetival, bot finally they

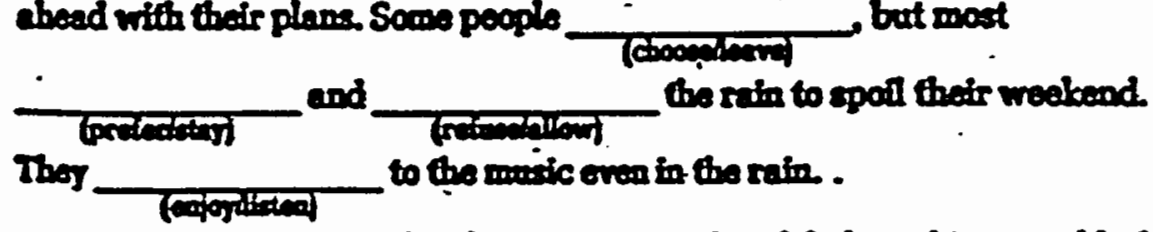

Nany of the rooms people who ceme to Woodetoct believed in a world of macia druger and freo love Thos work, and thoy Wooditock Nation. (oxperand an examplo for a now cociety. They called themosetros the Mingy of the boal towmepeoplo

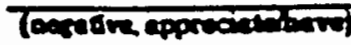
20 mang hippies

in their town and audity and drugs so neas their homes.

Some people (rosean - lot of trouble with so many people living logether in a small area for three days, but the visitore everything with cach other and (anoidaroul or with each other or the residents of Woodstoct. The local townspeople epprociateriser the extra business, but

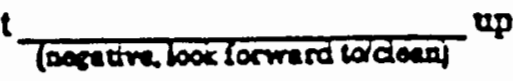
In the years after Woodstock many rock procooters (atrompopy this roct festival, bet they oll T(rivacbore the seme spirit of happiness, peace, and good music that the Woodstock festival symbolizod. 


\section{MICHAEL JACKSON \& HIS BROTHERS}

He was born in Gary, Indiana in 1958.

His parents intended him (be) a musician.

He started (play) the guitar at a young age.

He got his love for the guitar from his father who encouraged him (play) the guitar.

He practiced (play) every free minute.

He formed The Jackson Five in 1970.

Michael kept on (play).

The group enjoyed (perform) at local talent shows.

They began (practice) regularly.

In 1972 they decided (cut) "I'm a Big Boy Now." They began (work) for Motown Records.

Eventually Michael gave up his brothers. (do) records with

They wanted him (remain) with them.

He decided (stay) solo.

He made it big with hits like "Thriller" and "Billie Jean." He hopes (perform) at all the hot spots.

But he avoids (talk) to reporters if possible.

He resents (have) nosey people around all the time.

He would like (get married) someday but the right girl hasn't come along yet. 
NAME : DISCRETE POINT PRETEST

DATE :

AGE :

NATIONALITY :

How many months or years have you been in the United States?

How many years have you studied English?

Directions: Fill in the blanks using either the infinitive or gerund of the verbs in parentheses.

EXAMPLES: He was invited to lecture (lecture) at portland state. She hated riding (ride) the bus to work every day.

1. The defendant admitted (steal) the car.

2. They are preparing (go) to Africa next year.

3. I heard my neighbors (have) an argument last night.

4. Joan expects (enter) university next term.

5. Tom hopes (learn) Russian, but he hasn't started yet.

6. My father stopped (smoke) because it was bad for his health.

7. Please remind me Office. (take) this letter to the post

8. Finally she completed (write) her report.

9. Tammy dislikes (ride) the buses in China.

10. I can't afford (buy) a new car.

11. He forgot (lock) the door.

12. I smell something good (cook) in the oven.

13. She begged her husband not (leave) her but he ignored her plea.

14. She offered (lend) me her umbrella. 
15. The doctor is trying to persuade the patient

(remain) in the hospital a little longer.

16. They finished (paint) the house yesterday.

17. You should practice (speak) English every chance you get.

18. Many Portland residents resent (pay) high property taxes.

19. The man is pretending (be) a millionaire.

20. Tom denied (steal) the neighbor's dog. 
APPENDIX G

Chart of Preceding Verbs in Discrete Point Pretest

$\begin{array}{ll}\text { 1. admit } & - \text { G } \\ \text { 2. prepare } & - \text { I } \\ \text { 3. hear } & - \text { G } \\ \text { 4. expect } & - \text { I } \\ \text { 5. hope } & - \text { I } \\ \text { 6. stop } & - \text { G } \\ \text { 7. remind } & - \text { I } \\ \text { 8. complete } & - \text { G } \\ \text { 9. dislike } & \text { - G } \\ \text { 10. afford } & - \text { I }\end{array}$

11. forget

12. smell

13. beg

14. offer

15. persuade

16. finish

17. practice

18. resent

19. pretend

20. deny
$-I$

$-G$

$-I$

$-I$

- I

$-\mathrm{G}$

$-G$

$-G$

- I

$-G$

APPENDIX I

Chart of Preceding Verbs in Sentence Combining Pretest
1. resent $-G$
2. admit $-G$
3. dislike - G
4. agree $-I$
5. finish - G
6. deny $-G$
7. keep on $-G$
8. get used to $-G$
9. forget $-I$
10. complain $-\mathrm{G}$
$\star_{G}$ : gerund
I: infinitive

$\begin{array}{ll}\text { 11. enjoy } & - \text { G } \\ \text { 12. plan } & -I \\ \text { 13. excite } & - \text { G } \\ \text { 14. want } & -I \\ \text { 15. would 1ike } & -I \\ \text { 16. prepare } & -I \\ \text { 17. warn } & -I \\ \text { 18. decide } & -I \\ \text { 19. remind } & -I \\ \text { 20. hope } & -I\end{array}$

11. enjoy - G

- I

- G

I

- I

- I

- I

I 
APPENDIX H

SENTENCE COMBINING

NAME: PRETEST

DATE :

Directions: In each question you will be given two sentences and asked to combine them into one sentence by filling in missing words in a sentence frame. Use the infinitive or gerund form of the verb.

EXAMPLES: a. We will visit Italy this summer.

b. We look forward to that.

We look forward to visiting Italy this summer.

a. Janet exercises every day.

b. It is necessary for her.

It is necessary for Janet to exercise every day .

1. a. Portland residents pay high property taxes.

b. They resent it.

Portland residents resent

2. a. The boys threw stones at some parked cars.

b. They admitted their crime.

The boys admitted

3. a. Ann dislikes school.

b. Her mother makes her go anyway.

Even though Ann dislikes

her mother makes her anyway. to school,

4. a. The school imposed stricter discipline on the students.

b. The teachers agreed to it.

The teachers agreed

5. a. The carpenters built the house.

b. They finished it last week.

The carpenters finished

6. a. John was accused of drunk driving.

b. He denied it.

John denied under the influence of alcohol.

7. a. The police caught the thief in the act of stealing the car and yelled at him.

b. The thief ran.

The thief kept on

police yelled at him.

even though the 
8. a. I must work every other weekend.

b. I can't get used to that.

I can't get used to

9. a. The student didn't mail the letter.

b. He forgot.

The student forgot

10. a. The couple next door quarrel continuously.

b. People complain about this.

people complain about the couple's

11. a. We ski every winter in Colorado.

b. We enjoy it.

We enjoy

12. a. Tim hopes to go to graduate school.

b. His parents will pay for it.

Tim's parents plan

13. a. We will spend Thanksgiving with my grandparents.

b. We are excited.

We are excited about

14. a. I must go to the doctor for a physical.

b. I don't like it.

I don't want

15. a. Have lunch with me.

b. I would like this.

I would like you

16. a. The simpsons are going to the south seas this winter.

b. They are preparing for their trip.

The simpsons are preparing

17. a. My mom lost a lot of weight this summer.

b. Her doctor warned her about it.

My mom's doctor warned her not

18. a. Mary swept the floor.

b. Then she dusted the furniture.

After sweeping the floor, Mary decided

19. a. I am going to a staff meeting at 2:00 pm tomorrow.

b. Please remind me about it.

please remind me

20. a. I will go to Europe next year.

b. I hope it will work out.

I hope to Europe next year. 
Directions: Fill in the blanks using either the infinitive or gerund form of the verbs in parentheses.

EXAMPLES: She enjoys watching (watch) television. She hopes to go (go) to Spain one day.

1. She completed (write) her term paper one hour before class.

2. We hope (see) you graduate next year.

3. I heard my mother with my brother. (tell) my father about my fight

4. Rick plans (ask) his parents for a computer for Christmas.

5. The boys admitted (start) the fire which burned down some homes.

6. When will you finish (read) that book?

7. Gary denied his mother didn't believe him. (take) the last piece of pie but

8. Marsha chose movie. (stay) home instead of going to the

9. Glenn agreed but it never materialized. (help) his son start up a lawn service

10. Michael Jackson practiced (play) the guitar every day.

11. The teacher encouraged me when I write. (be) more careful

12. John dislikes (read) literature.

13. Anna detests makes her do it anyway. (clean) up her room but her mother

14. Please remind me the way home. (stop) for a loaf of bread on 
15. Mike dreads (wake) up so early every morning.

16. My friend offered (lend) me her notes for the class I'd missed.

17. Mrs. Smith persuaded jane not (drop out) of school but Jane's mind was already made up.

18. Tom's father warned him (be) careful with the car.

19. My neighbor promises sometimes she isn't always successful. (keep) her dog in her yard, but

20. After their quarrel they stopped (talk) to each other for a month. 
Chart of Preceding Verbs in Discrete Point Posttest

$\begin{array}{ll}\text { 1. complete } & - \text { G } \\ \text { 2. hope } & - \text { I } \\ \text { 3. hear } & - \text { G } \\ \text { 4. plan } & - \text { I } \\ \text { 5. admit } & - \text { G } \\ \text { 6. finish } & - \text { G } \\ \text { 7. deny } & - \text { G } \\ \text { 8. choose } & - \text { I } \\ \text { 9. agree } & - \text { I } \\ \text { 10. practice } & - \text { G }\end{array}$

11. encourage - I

12. dislike $-G$

13. detest $-G$

14. remind - I

15. dread $-G$

16. offer $-I$

17. persuade $-I$

18. warn $-I$

19. promise $-I$

20. stop $-G$

APPENDIX M

Chart of Preceding Verbs in Sentence Combining Posttest

\begin{tabular}{|c|c|c|c|}
\hline 1. admit & $-G$ & 11. would like & $-I$ \\
\hline 2. dislike & $-G$ & 12. prepeare & $-I$ \\
\hline 3. deny & $-G$ & 13. decide & $-I$ \\
\hline 4. keep on & $-G$ & 14. complain & $-G$ \\
\hline 5. forget & $-I$ & 15. resent & $-G$ \\
\hline 6. agree & $-I$ & 16. warn & $-I$ \\
\hline 7. enjoy & $-G$ & 17. finish & $-G$ \\
\hline 8. plan & $-I$ & 18. remind & $-I$ \\
\hline 9. excite & $-G$ & 19. stop & $-G$ \\
\hline 10. want & $-I$ & 20. get used to & $-G$ \\
\hline
\end{tabular}




\author{
SENTENCE COMBINING \\ NAME : POSTTEST \\ DATE:
}

Directions: In each question you will be given two sentences and asked to combine them into one sentence by filling in missing words in a sentence frame. Use the infinitive or gerund form of the verb.

EXAMPLES: a. We will visit Italy this summer.

b. We look forward to that.

We look forward to visiting Italy this summer.
a. Janet exercises every day.
b. It is necessary for her.
It is necessary for Janet to exercise every day.

1. a. The boys stole the neighbor's hubcaps.

b. They admitted it.

The boys admitted

2. a. Marsha dislikes preschool.

b. Her mother makes her go anyway.

Even though Marsha dislikes

her mother makes her anyway. to pre-school,

3. a. Bob was accused of cheating on his test.

b. He denied it.

Bob denied

4. a. Ian caught his cat in the act of stealing the fish and yelled at him.

b. The cat ate the fish.

The cat kept on even though he yelled at him.

5. a. Some of my students didn't do their homework.

b. They forgot.

Some of my students forgot

6. a. Kim's parents imposed restrictions on watching T.V.

b. They agreed to it. Kim's parents agreed

7. a. We sail every summer on lake Dillion.

b. We enjoy it.

We enjoy 
8. a. Jenny hopes to go to India.

b. Her parents will pay for it. Jenny's parents plan

9. a. We will spend Christmas with my family.

b. We are excited.

We are excited about

10. a. I must go to the dentist.

b. I don't like it.

I don't like

11. a. Have dinner with me.

b. I would like this.

I would like you

12. a. The Johnsons are sailing around the world next spring

b. They are preparing for their trip.

The Johnsons are preparing

13. a. Pat answered the correspondence.

b. Then she typed the letters.

After answering the correspondence, Pat decided

14. a. Our neighbors argue a lot.

b. People complain about it.

People complain about our neighbors'

15. a. Denver residents pay a high sales tax.

b. They resent it. Denver residents resent

16. a. My Dad smokes too much.

b. The doctor warned him about it.

The doctor warned my dad not

17. a. The painters painted our classroom.

b. They finished it yesterday.

The painters finished

18. a. I am going to a football game at 7:00 pm tomorrow night.

b. Please remind me about it.

please remind me

19. a. My dad doesn't drink any more.

b. He stopped last year.

My dad stopped

20. a. Timmy must work nights.

b. He can't get used to that.

Timmy can't get used to 
APPENDIX N

Verbs wich do not fit the Bolinger Principle

$\begin{array}{ll}\text { GERDNDS } & \text { IMFINITIVEd } \\ \text { imagine } & \text { manage } \\ \text { anticipate } & \text { continue } \\ \text { consider } & \text { fail } \\ \text { keep } & \text { get } \\ \text { mind } & \text { have } \\ \text { postpone } & \text { claim } \\ \text { suggest } & \text { teach } \\ \text { understand } & \text { hire } \\ \text { delay } & \text { tell } \\ \text { envision } & \\ \text { recommend } & \\ \text { risk } & \end{array}$

